UNIVERSIDADE DE SÃO PAULO

FACULDADE DE OdONTOLOGIA DE RIBEIRÃo PRETO

\title{
EFEITO do Uso SistÊmico de ALENDRONATO Sódico No TECIDO ÓSSEO E NAS ESTRUTURAS DENTÁRIAS MineralizadAS: Estudo QUÍMICO, MeCÂNICO E MORFOLÓGICO, EM MODELO MURINO
}




\title{
EFEITO do Uso SistêmICO de ALENDRONATO Sódico NO TECIDO ÓSSEO E NAS ESTRUTURAS DENTÁRIAS Mineralizadas: Estudo QuÍMICO, MECÂNICO E MORFOLÓgICO, EM MOdELO MURINO
}

\author{
Dissertação apresentada à Faculdade de \\ Odontologia de Ribeirão Preto da \\ Universidade de São Paulo, para \\ obtenção do Título de Mestre em \\ Odontopediatria.
}

Orientador: Prof. Dr. Paulo Nelson-Filho 
AUTORIZO A REPRODUÇÃO E DIVULGAÇÃO TOTAL OU PARCIAL DESTE TRABALHO, POR QUALQUER MEIO CONVENCIONAL OU ELETRÔNICO, PARA FINS DE ESTUDO E PESQUISA, DESDE QUE CITADA A FONTE.

FICHA CATALOGRÁFICA

Lucisano, Marília Pacífico

Efeito do uso sistêmico de alendronato sódico no tecido ósseo e nas estruturas dentárias mineralizadas: Estudo químico, mecânico e morfológico, em modelo murino. Ribeirão Preto, 2010.

84 p. : il. ; $30 \mathrm{~cm}$

Dissertação de Mestrado apresentada à Faculdade de Odontologia de Ribeirão Preto/USP - Área de Concentração: Odontopediatria.

Orientador: Nelson-Filho, Paulo

1. Alendronato sódico 2. Esmalte 3. Dentina 4. Densidade mineral óssea

5. Microdureza transversal 6. Microscopia eletrônica de varredura 7. Microscopia de luz polarizada 


\section{EfEITO do Uso Sistêmico de AlendRonAto Sódico no Tecido Ósseo e nas Estruturas DentáRIas Mineralizadas: Estudo Químico, MecÂnico e Morfológico, em Modelo MURINO}

Dissertação apresentada à Faculdade de Odontologia de Ribeirão Preto da Universidade de São Paulo, para obtenção do Título de Mestre em Odontopediatria.

Data da defesa:

Banca Examinadora

Prof. Dr.

Instituição:

Julgamento: Assinatura:

Prof. Dr.

Instituição:

Julgamento: Assinatura:

Prof. Dr.

Instituição:

Julgamento: Assinatura: 


\title{
Dados CURriculares
}

\author{
MARÍLIA PACÍFICO LUCISANO
}

Nascimento

25 de novembro de 1985 - Ribeirão Preto/SP

Filiação

Renilton Nazareno Fontes Lucisano

Maria Stella Alves Pacífico Lucisano

2004-2007

Curso de Graduação

Faculdade de Odontologia de Ribeirão Preto da Universidade de São Paulo

2008-2010

Curso de Pós-Graduação (Mestrado) em Odontologia Área de Concentração: Odontopediatria

Faculdade de Odontologia de Ribeirão Preto/USP 


\section{DEDICÁTORIA}

A Deus, pela vida e por Tua constante presença.

Obrigada por me guiar, me proteger e iluminar o meu

caminho.

Obrigada pela esperança que animou meus passos,

obrigada pelos exemplos que recebi,

obrigada pelo que me fez sofrer, pois nos momentos de

desânimo, Tu me enchestes de luz,

obrigada pela compreensão e pelo amor que encontrei

nas pessoas que Tu pusestes em meu caminho,

obrigada por esta conquista.

"A luz de Deus me cura.

$O$ amor de Deus me envolve.

O poder de Deus me protege.

A presença de Deus vela por mim.

Onde quer eu esteją, Deus aî estā."

(Regis Castro e Maisa Castro, 1994)

Aos meus pais Maria Stella Alves Pacífico Lucisano e Renilton Nazareno Fontes Lucisano, pelo amor incondicional e pela admirável arte de educar. Obrigada por me ensinar a caminhar seguindo os princípios de Deus e por terem me proporcionado uma vida repleta de felicidade. Agradeço a vocês por não medirem esforços para investir na minha educação e me incentivar a continuar estudando sempre. Mamãe e Bem, obrigada pelo amor, segurança, apoio e compreensão que encontro em vocês e, principalmente, pelo porto seguro em momentos de dificuldade.

Esta conquista também é de vocês.

Obrigada por acreditarem em mim! Amo vocês. 


\begin{abstract}
À minha querida irmã Marcela Pacífico Lucisano, minha melhor amiga! Obrigada pelo seu amor, força, incentivo e amizade. Agradeço por eu poder dividir com você tudo em minha vida. Você é minha melhor e eterna companheira. Amo você!
\end{abstract}

\begin{abstract}
À minha tia Regina Célia Lucizani Müller, exemplo de amor à vida e à profissão! Muito obrigada pelo incentivo e apoio em todos os momentos dessa trajetória. Tia Regina, muito te admiro por sua dedicação, força e coragem! Obrigada por seu amor e carinho.
\end{abstract}

A todos os familiares e amigos que sempre torceram por mim e me deram carinho! 


\section{AGRADECIMENTO ESPECIAL}

Ao meu orientador Prof. Dr. Paulo Nelson-Filho, por transmitir seus conhecimentos e experiências profissionais e de vida com dedicação e carinho, por me guiar para além das teorias, das filosofias e das técnicas. Expresso meu sincero agradecimento e meu profundo respeito, que sempre serão pouco diante do muito que me ofereceu.

Obrigada, pela gentileza especial, compreensão e estímulo que sempre vêm tão naturalmente de você.

Professor, você é meu Mestre, meu exemplo de ser humano, meu modelo de inspiração. Serei eternamente sua discípula, seguirei seus princípios de humildade, respeito incomparável, lealdade e seu admirāvel exemplo de dedicação plena e amor ao Ensino.

Agradeço pelas palavras, tempo e atenção dedicados a mim e pela orientação na minha formação profissional.

Tenho muito orgulho de ser sua aluna. Agradeço a

Deus por ter você no meu caminho!

Obrigada por ter acreditado em mim. 


\title{
AGRADECIMENTOS
}

À Profa. Dra . Léa Assed Bezerra da Silva, por ter me recebido e acolhido na Odontopediatria. Obrigada por acreditar na minha capacidade e pelo incentivo constante ao aprendizado e à pesquisa.

\begin{abstract}
A Profa. Dra. Raquel Assed Bezerra da Silva, pela forma carinhosa e amiga que me recebeu. Agradeço pela sua dedicação, apoio e atenção, desde o início, que me motivaram a cada instante nesta trajetória. Raquel, a forma tão prestativa, alegre e gentil com a qual você se dirige a todas as pessoas é admirável. Agradeço pelos seus ensinamentos e, principalmente, pela sua fundamental colaboração na realização deste trabalho. Obrigada por compartilhar comigo seu valioso conhecimento científico e profissional e pela grande amizade que encontrei em você.
\end{abstract}

\begin{abstract}
À Profa. Dra . Alexandra Mussolino de Queiroz, pela forma alegre e carinhosa com que sempre me acolhe. Obrigada pelo incentivo e dedicação para me ajudar em tudo que eu preciso. Sou grata pelos seus ensinamentos e pela contribuição na minha formação profissional. Danda, obrigada pela atenciosa e agradável convivência.
\end{abstract}

À Prof .Dra .Kranya Victória Díaz Serrano, pela sua alegria, otimismo e dedicação. Obrigada por estar sempre disponivel, pelo incentivo constante e pelas conversas agradáveis. 
À Profa. Dra . Maria Cristina Borsatto, ótima companheira para todas as horas. Exemplo de bom-humor e alegria. Cris, obrigada pelo estímulo e por estar sempre à disposição para ajudar.

À Profa. Dra . Sada Assed, pelos princípios de determinação, amor à vida e dedicação ao Ensino.

\begin{abstract}
A Profa. Dra. Aldevina Campos de Freitas, grande exemplo de dedicação, paciência e amor à profissão. Professora, muito obrigada pelos conhecimentos teóricos e clínicos transmitidos desde a graduação.
\end{abstract}

Ao Prof. Dr. Mário Roberto Leonardo, exemplo de simpatia, respeito, humildade e amor ao próximo. Meu sincero agradecimento por todos os seus preciosos ensinamentos que serão sempre lembrados por mim.

A Faculdade de Odontologia de Ribeirão Preto da Universidade de São Paulo, na pessoa do atual diretor Prof.

Dr. Osvaldo Luiz Bezzon e do Vice-Diretor Prof. Dr. Valdemar Mallet da Rocha Barros.

À Coordenação do Curso de Pós-Graduação em Odontopediatria da Faculdade de Odontologia de Ribeirão Preto da Universidade de São Paulo, na pessoa da Coordenadora Profa. Dra. Léa Assed Bezerra da Silva e do Vice-Coordenador Prof. Dr. Paulo Nelson-Filho. 
Aos Professores do Departamento de Clínica Infantil, Odontologia Preventiva e Social da Faculdade de Odontologia de Ribeirão Preto da Universidade de São Paulo Profa. Dra . Sada Assed, Profa. Dra . Léa Assed Bezerra da Silva, Profa. Dra. Aldevina Campos de Freitas, Prof. Dr. Paulo Nelson-Filho, Profe. Dra . Alexandra Mussolino de Queiroz, Prof. Dr. Mário Roberto Leonardo, Profa . Dra . Kranya Victória Díaz Serrano, Profa. Dra. Maria Cristina Borsatto, Profa. Dra. Raquel Assed Bezerra da Silva, Profa. Dra. Mírian Aiko Nakane Matsumoto, Prof. Dr. José Tarcísio Lima Ferreira, Prof. Dr. Adílson Thomazinho, Profa. Dra. Maria Bernadete Sasso Stuani, Profa. Dra. Maria da Conceição Pereira Saraiva, Prof. Dr. Fábio Lourenço Romano e Prof ${ }^{\text {a }}$ Dra . Andiara De Rossi, pela agradável convivência, pelas conversas atenciosas e pelos valiosos ensinamentos durante a minha formação acadêmica e científica.

\begin{abstract}
A Profa. Dra. Mônica Campos Serra do Departamento de Odontologia Restauradora da FORP/USP, pelo apoio oferecido, pelas importantes contribuições científicas e pela fundamental colaboração na realização deste trabalho. Professora, obrigada por abrir as portas do seu laboratório para que eu pudesse trabal har e por ter acreditado em mim.
\end{abstract}

Ao Prof. Dr. Roberto Santana da Silva do Departamento de Fîsica e Química da Faculdade de Ciências Farmacêuticas de Ribeirão Preto (USP), por ter me recebido com tanto carinho e atenção. Obrigada pela oportunidade de realizar parte do meu trabalho com sua equipe e pelas valiosas contribuições científicas. Meu sincero agradecimento pela disponibilidade e pelos conhecimentos transmitidos. 
A Profa. Dra. Leslie Morse da Medical School - Harvard University - USA e ao Prof. Dr. Ricardo Battaglino do The Forsyth Institute - Harvard University - USA, meu sincero agradecimento pela gentileza, atenção e pela fundamental colaboração na realização deste trabalho.

Prof. Dr. Plauto Christopher Aranha Watanabe do Departamento de Morfologia, Estomatologia e Fisiologia da FORP/USP, pela atenção e disponibilidade.

A Profa. Dra. Raquel Fernanda Gerlach do Departamento de Morfologia, Estomatologia e Fisiologia da FORP/USP, pela oportunidade oferecida de enriquecer o meu trabalho e por ter me recebido com muito carinho e atenção em seu laboratório.

Ao Prof. Dr. Alberto Consolaro da Faculdade de Odontologia de Bauru - USP e à Profa. Dra . Maria Fernanda Martins-Ortiz Consolaro da Faculdade de Odontologia da Universidade do Sagrado Coração (USC), Bauru/SP, meu sincero agradecimento pelo incontestável profissionalismo, pelo estímulo para a realização deste trabalho, pela atenção, disponibilidade e dedicação constante.

\section{À Faculdade de Ciências Agrărias e Veterinărias da UNESP de} Jaboticabal, pela oportunidade concedida na realização de parte do meu trabalho.

À Prof ${ }^{a}$. Dra . Maria da Conceição Pereira Saraiva, pela atenção, por estar sempre disponível e pelo auxílio e orientação na análise estatística dos resultados. 
Ao Dr. Milton Santamaria-Junior, pela forma gentil e atenciosa com que participou desde o início deste trabalho. Agradeço pelos ensinamentos, pelas dúvidas compartilhadas e por estar sempre disponível para ajudar.

Às amigas da Pós-Gradução Paula Dariana Fernandes Ferreira e Késsia Suênia Fidelis de Mesquita, por terem sido mais do que especiais. Obrigada por terem me ajudado desde o início deste trabalho e nos momentos mais dificeis, nos quais vocês sempre estiveram ao meu lado, me apoiando e me auxiliando na execução da parte experimental. Agradeço pelo convívio, companheirismo, pelas risadas e, acima de tudo, pela amizade construída. Paula, agradeço do fundo do coração por você ter se dedicado e se envolvido com este trabalho, como se ele fosse seu.

A Zumira Aparecida Carneiro, pós-graduanda do Departamento de Fîsica e Química da Faculdade de Ciências Farmacêuticas de Ribeirão Preto (USP), e ao pós-graduando Francisco Carlos Rehder Neto, pela forma gentil e atenciosa que sempre me atenderam e por terem oferecido seu tempo para me auxiliar em várias etapas deste trabalho. Muito obrigada pelo apoio oferecido, pelas conversas agradáveis e, especialmente, pela importante ajuda que recebi de vocês sempre que precisei.

A pós-graduanda Cristiane Tomaz Rocha, pelo companheirismo, pela amizade, pela disponibilidade para ajudar em tudo que precisei e pela colaboração durante a documentação fotográfica. 
À pós-graduanda Giselle de Angelo Souza Leite, pela disponibilidade e auxílio na realização da parte experimental com os ratos.

À pós-graduanda Cintia Guimarães de Almeida, pela pessoa maravilhosa e iluminada que é. Cíntia, muito obrigada pela ajuda que sempre me ofereceu e que, com certeza, foi importante na realização deste trabalho.

Aos amigos da Pós-Graduação, Camila Scatena, Cintia Guimarães de Almeida, Danielle Torres Azevedo, Luciane Almeida do Carmo, Marcela Martin Del Campo Fierro, Paula Dariana Fernandes Ferreira, Rodrigo Alexandre Valério, Talitha de Siqueira Mellara, Elaine Machado Pingueiro, Fernanda Regina Ribeiro Santos, Iliana Ferraz Sabbatini, Késsia Suênia Fidelis de Mesquita, Ligia Maria Napolitano Gonçalves, Carolina Paes Torres Mantovani, Cristhiane Ristum Bagatin Rossi, Cristiane Tomaz Rocha, Fabrício Kitazono de Carvalho, Jaciara Miranda Gomes da Silva, Maristela Soares Swerts Pereira, Regina Aparecida Segatto Saiani, Rodrigo Teixeira Macri, Soraya Cheier Dib Gonçalves, Cristina Bueno Brandão, Kleber Cortês Bonifacio, Larissa Moreira Spinola de Castro, Leonardo Bíscaro Pereira, Marcela C. D. Andrucioli, Marina Fernandes de Sena, Marta Maria Martins Giamatei Contente, Walter Raucci Neto, Maya Fernanda Manfrin Arnez e Milena Silva Campos, pela agradável convivência, pelo companheirismo, pelos valiosos momentos compartilhados, pelo apoio, incentivo e amizade.

Ao Wagner dos Santos Garrido, meu namorado, companheiro e amigo, pelo carinho e apoio em todos os momentos. Wa, obrigada por acreditar em mim, por me incentivar na realização dos meus sonhos e por estar sempre ao meu lado! Você é muito especial e seu companheirismo foi fundamental na realização desta conquista. 
A minha grande amiga Lariça Barbosa Raimundo, pelos valiosos momentos que passamos juntas. Saiba que tenho você como uma irmã, que conquistei desde a graduação. Você sempre está ao meu lado, disposta a me ajudar e me apoiar em tudo que preciso. La, obrigada pelos conselhos, pelas conversas, risadas e, principalmente, pelo incentivo e carinho. Para mim é um privilégio tê-la como amiga. Saiba que você tem e sempre terá um lugar reservado no meu coração.

À minha prima Flávia Lucisano Botelho do Amaral, por ter me ajudado desde o início da graduação e me apoiado sempre. Fá, obrigada pelo incentivo na escolha deste caminho e, principalmente, pelos bons momentos que passamos juntas.

Aos meus amigos Lívia Alves Corrêa Moretti, Nathâlia de Queiroz Ribeiro, Larissa Ayres Ferreira, Thaís Parizi Gonçalves, Luiz Fernando Scali Mathias Duarte, Márcio Buffoni D'Ávila e Silva e Guilherme Maluf Palei Benedecti, por terem dividido comigo os melhores momentos da minha vida e por me incentivarem e acreditarem em mim sempre. Vocês são inesquecíveis!

Aos funcionários do Departamento de Clínica Infantil, Odontologia Preventiva e Social da Faculdade de Odontologia de Ribeirão Preto da Universidade de São Paulo, Micheli Cristina Leite Rovanholo, Filomena Leli Placciti, Francisco Wanderley Garcia de Paula e Silva, Carolina Paes Torres Mantovani, Marco Antonio dos Santos, Carmo Euripedes Terra Barretto, Dorival Gaspar, Nilza Letícia 
Magalhães, Fătima Aparecida Rizoli, Fătima Aparecida Jacinto Daniel, Renata Aparecida Fernandes e Matheus Morelli Zanela, pela alegre convivência, amizade, paciência e prontidão para nos atender. Muito Obrigada.

Aos funcionários do Biotério Antônio Sérgio Aparecido Mesca e Antônio Massaro, pela gentileza e bom-humor com que me receberam diariamente. Obrigada por terem sido tão prestativos e atenciosos e pelo cuidado no tratamento dos animais.

Às funcionárias da Seção de Pós-Graduação da Faculdade de Odontologia de Ribeirão Preto da Universidade de São Paulo, Isabel Cristina Galino Sola e Regiane Cristina Moi Sacilloto, pela atenção e por estarem sempre à disposição.

À CAPES (Coordenação de Aperfeiçoamento de Pessoal de Nivel Superior), pela bolsa concedida.

\footnotetext{
À Amélia Regina Azevedo Aguena Albuquerque, pela forma simpática, alegre e acolhedora com que me recebeu. Muito obrigada pela prontidão em me atender e, principalmente, por ter elaborado os maravilhosos fluxogramas deste trabalho.
}

Ao Júlio César de Matos, Clăudia Regina Corrêa de Matos e Rosemary Alves pela diagramação e impressão desse trabalho. 


\section{RESUMO}

Lucisano, MP. Efeito do uso sistêmico de alendronato sódico no tecido ósseo e nas estruturas dentárias mineralizadas: Estudo químico, mecânico e morfológico, em modelo murino. Ribeirão Preto, 2010. 84 p. Dissertação [mestrado] - Faculdade de Odontologia de Ribeirão Preto, Universidade de São Paulo.

Os bisfosfonatos representam uma classe de drogas que agem sobre o metabolismo ósseo e são amplamente utilizadas na prevenção e tratamento de estados osteopênicos e osteoporóticos. Os objetivos do presente estudo foram avaliar, in vivo, o efeito do uso sistêmico de alendronato sódico: na densidade mineral óssea de ratos, por meio da densitometria óptica radiográfica e da técnica de absortometria radiológica de dupla energia (DXA); e nas estruturas dentárias mineralizadas de incisivos murinos, por meio da espectrometria na região do infravermelho, espectroscopia de fluorescência, microdureza transversal, microscopia eletrônica de varredura e microscopia de luz polarizada. Foram utilizados 45 ratos Wistar, com 36-42 dias de idade, pesando em média 200-230g, os quais foram divididos em dois grupos: experimental $(n=25)$ e controle $(n=20)$. No grupo experimental foram administradas duas doses semanais de $1 \mathrm{mg} / \mathrm{Kg}$ de alendronato de sódio quimicamente puro diluído em água destilada, via gavagem, enquanto que os animais do grupo controle receberam apenas água destilada. Decorrido o período de 60 dias, os animais foram mortos por sobredose anestésica e, em seguida, foram extraídos os incisivos superiores e removidas as tíbias. As tíbias foram submetidas à avaliação da densidade mineral óssea por meio de análise radiográfica e da técnica de absortometria radiológica de dupla energia (DXA). Os incisivos superiores foram submetidos às seguintes avaliações: análise química por espectrometria na região do infravermelho e espectroscopia de fluorescência, microdureza transversal do esmalte e da dentina; microscopia eletrônica de varredura e microscopia de luz polarizada. Os resultados numéricos obtidos foram submetidos à análise estatística por meio do teste não-paramétrico de Kruskal-Wallis, utilizando o software SAS (Statistical Analysis System) for Windows versão 9.1.3. O nível de significância adotado foi de $5 \%$. O grupo experimental apresentou valores de densidade mineral óssea superiores $(p<0,05)$ em relação ao grupo controle, pelos métodos da densitometria óptica radiográfica e DXA. A análise química pelos métodos de espectrometria na região do infravermelho e espectroscopia de fluorescência permitiu detectar a presença do alendronato na estrutura dentária mineralizada do grupo experimental e que a porcentagem dessa incorporação foi de $0,0018 \%$ por elemento dental. Os resultados da microdureza transversal do esmalte e da dentina não revelaram diferença estatisticamente significante entre os grupos experimental e controle ( $p>0,05)$. Não foram observadas diferenças morfológicas significativas entre as amostras de ambos os grupos por meio da análise por microscopia eletrônica de varredura e microscopia de luz polarizada. Com base nos resultados obtidos, conclui-se que o tratamento com alendronato sódico provocou aumento na densidade mineral óssea 
da metáfise proximal da tíbia e que o alendronato incorporou-se nas estruturas dentárias mineralizadas, porém sem provocar efeitos significativos na microdureza e na morfologia do esmalte e da dentina de incisivos de ratos.

Palavras-chave: Alendronato sódico, Esmalte, Dentina, Densidade mineral óssea, Microdureza transversal, Microscopia eletrônica de varredura, Microscopia de luz polarizada. 


\section{ABSTRACT}

Lucisano, MP. Effect of the systemic use of sodium alendronate on bone tissue and mineralized dental structures: A chemical, mechanical and morphological study in a murine model. Ribeirão Preto, 2010. 84 p. Dissertação [mestrado] - Faculdade de Odontologia de Ribeirão Preto, Universidade de São Paulo.

Bisphosphonates represent a class of drugs that act on bone metabolism and are widely used in the prevention and treatment of osteopenic and osteoporotic states. The objectives of this study were to evaluate, in vivo, the effect of the systemic use of sodium alendronate on: the mineral bone density of rats, by radiographic optical densitometry and dual-energy x-ray absorptiometry (DXA); the mineralized dental structures of murine incisors, by analysis of infrared (IR) spectrometry, fluorescence spectroscopy, cross-sectional microhardness (CSMH), scanning electron microscopy (SEM) and polarized light microscopy (PLM). Forty-five Wistar rats aged 36-42 days and weighing 200$230 \mathrm{~g}$ were assigned to two groups: experimental $(n=25)$ and control $(n=20)$. The experimental group received two weekly doses of $1 \mathrm{mg} / \mathrm{kg}$ of chemically pure sodium alendronate diluted in distilled water, via gavage, while the animals of the control group received only distilled water. After 60 days, the animals were killed by anesthetic overdose, and the maxillary incisors were extracted and the tibias were removed. The mineral bone density of the tibias was analyzed radiographically and by DXA. The maxillary incisors were subjected to the following evaluations: chemical analysis by IR spectrometry and fluorescence spectroscopy, enamel and dentin CSMH, SEM and PLM. The results were subjected to statistical analysis by the Kruskal-Wallis non-parametric test, using the SAS (Statistical Analysis System) software for Windows version 9.1.3. The significance level was set at $5 \%$. The experimental group presented higher mineral bone density $(p<0.05)$ than the control group, by radiographic optical densitometry and DXA. The chemical analysis by IR spectrometry and fluorescence spectroscopy revealed the presence of alendronate in the mineralized dental structure of the specimens of the experimental group, with a percentage of incorporation of $0.0018 \%$ per tooth. The results of enamel and dentin CSMH did not show statistically significant difference between the experimental and control groups ( $p>0.05$ ). There were no significant morphological differences among the specimens of the groups by SEM and PLM. Based on the obtained results, it may be concluded that the treatment with sodium alendronate caused an increase in the mineral bone density of the proximal tibial metaphysis, and that alendronate was incorporated in the mineralized dental structures without causing significant effects in the enamel and dentin microhardness and morphology of rat incisors.

Key words: Sodium alendronate, enamel, dentin, mineral bone density, cross-sectional microhardness, scanning electron microscopy, polarized light microscopy. 


\section{SUMÁRIO}

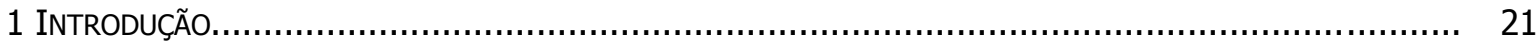

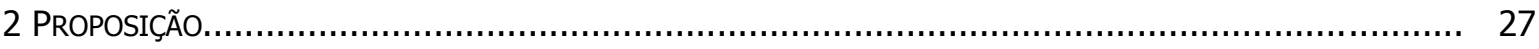

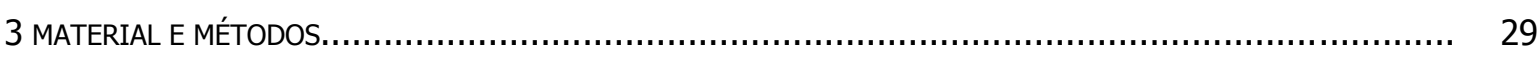

3.1 Análise da Densidade Mineral Óssea Radiográfica e por meio da Técnica de Absortometria Radiológica de Dupla Energia (DXA).......................................... 33

3.2 Análise Química Qualitativa da Incorporação do Alendronato Sódico nas Estruturas Dentárias Mineralizadas (Esmalte e Dentina) por Espectrometria na Região do Infravermelho.

3.3 Análise Química Quantitativa da Incorporação do Alendronato Sódico nas Estruturas Dentárias por Espectroscopia de Fluorescência.

3.4 Avaliação do Efeito da Incorporação do Alendronato Sódico nas Estruturas Dentárias Mineralizadas. 42

Análise da Microdureza Transversal. 42

Análise por Microscopia Eletrônica de Varredura......................................................... 45

Análise por Microscopia de Luz Polarizada................................................................... 47

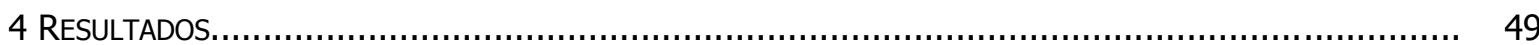

4.1 Análise da Densidade Mineral Óssea Radiográfica e por meio da Técnica de Absortometria Radiológica de Dupla Energia (DXA).............................................. 50

4.2 Análise Química Qualitativa da Incorporação do Alendronato Sódico nas Estruturas Dentárias Mineralizadas (Esmalte e Dentina) por Espectrometria na Região do Infravermelho

4.3 Análise Química Quantitativa da Incorporação do Alendronato Sódico nas Estruturas Dentárias por Espectroscopia de Fluorescência.

4.4 Avaliação do Efeito da Incorporação do Alendronato Sódico nas Estruturas Dentárias Mineralizadas.

Análise da Microdureza Transversal................................................................. 56

Análise por Microscopia Eletrônica de Varredura....................................................... 57

Análise por Microscopia de Luz Polarizada............................................................ 58

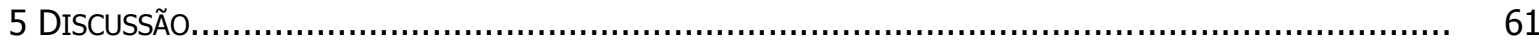

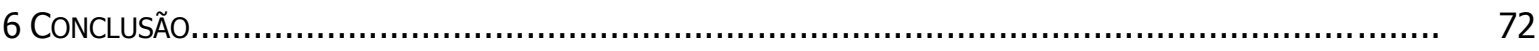

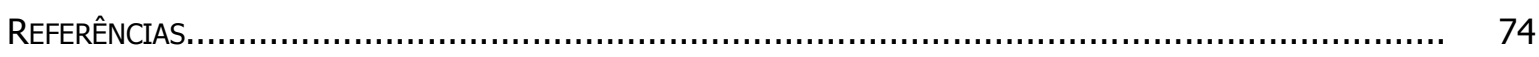

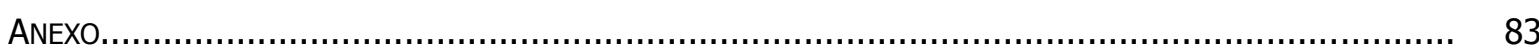




\section{Introdução}




\section{INTRODUÇÃO}

Os bisfosfonatos (BFs) representam uma classe de drogas que agem sobre o metabolismo ósseo e são amplamente utilizadas na prevenção e tratamento de estados osteopênicos e osteoporóticos, como a Doença de Paget, a osteoporose e a hipercalcemia maligna (Fleisch, 1998; Vasikaran, 2001; Drake et al., 2001; Russell et al., 2007; 2008; Inoue et al., 2008; Bachrach e Ward, 2009; Lewiecki, 2010; Kawate et al., 2010; Pazianas et al., 2010; Reid, 2010; Drake e Cremers, 2010; Watts e Diab, 2010). Observa-se nessas patologias uma hiperatividade das unidades osteorremodeladoras, em especial dos clastos, que atuam diretamente sobre a superfície óssea, retirando os íons minerais pela liberação de ácidos na sua interface, via borda pregueada. Os clastos também degradam a parte óssea orgânica ou matriz óssea, pela liberação de enzimas proteolíticas, especialmente a colagenase (Consolaro, 2005; Russell et al., 2007).

Os BFs são análogos não-hidrolizáveis do pirofosfato, um regulador endógeno da mineralização, tendo em vista que contêm ligações estáveis P-C-P em vez de ligações lábeis P-O-P (Russell et al., 2008; Ghoneima et al., 2010). No entanto, apresentam efeitos similares ao pirofosfato nos tecidos mineralizados, como inibir a formação e dissolução de cristais de hidroxiapatita e prevenir calcificações ectópicas nas artérias, pele e em outros órgãos (Larsson e Larsson, 1973; Fleish, 2002; Russell, 2007). A estrutura P-C-P confere aos BFs a capacidade de ligação a íons divalentes, como o cálcio (Rogers et al., 2000). Por esta razão, os BFs são rapidamente retirados da circulação e direcionados às superfícies ósseas in vivo, em locais de remodelação óssea ativa, particularmente em áreas que estão sofrendo reabsorção osteoclástica. Este mecanismo faz com que os BFs sejam atraídos e armazenados no tecido ósseo, até que sejam liberados localmente por meio do processo reabsortivo (Roelofs et al., 2006).

O grupo P-C-P torna a molécula resistente tanto à hidrólise química quanto à enzimática. Todos os BFs empregados do ponto de vista clínico apresentam dois grupos fosfonatos, que dividem um átomo de carbono em comum, os quais possuem uma dupla função: são necessários para a ligação ao mineral ósseo e para a atividade antirreabsortiva mediada por células (Russell et al., 2008). Modificações em um ou em ambos os grupos fosfonatos podem reduzir drasticamente a afinidade dos BFs pelo mineral ósseo, bem como reduzir sua potência bioquímica (Ebetino et al., 1998).

As cadeias laterais R1 e R2 ligadas ao átomo de carbono são responsáveis pela larga variação de atividade observada entre os BFs. Os substituintes R1, tais como hidroxila ou amino, melhoram a quimioabsorção ao mineral (Van Beek et al., 1996), enquanto que a variação dos substituintes R2 resulta em diferenças na potência antirreabsortiva de várias ordens de magnitude (Ebetino et al., 1998). 
A afinidade pronunciada dos BFs pelo osso é a base para seu valor na prática clínica. Sua captação e adsorção preferenciais às superfícies minerais nesse tecido permitem um contato próximo com os osteoclastos. Durante a reabsorção óssea os BFs, provavelmente, são internalizados nas células por endocitose juntamente com outros produtos da reabsorção (Sato et al., 1991; Salo et al., 1997; Thompson et al., 2006).

Segundo Boivin e Meunier (2002), o principal mecanismo pelo qual os BFs inibem a reabsorção óssea é por meio de seus efeitos diretos nos osteoclastos. Entretanto, de acordo com estes autores, não se deve excluir a possibilidade de que pequenas quantidades destas drogas sejam internalizadas por células vizinhas, como osteoblastos, células da medula óssea ou células tumorais, principalmente após administrações freqüentes durante um prolongado período de tempo.

Sahni et al. (1993) sugeriram que parte da inibição da atividade dos osteoclastos pelos BFs seria mediada pela ação de osteoblastos, pois a diminuição do agente estimulatório encontrado no meio condicionado por estas células inibiria a atividade reabsortiva dos clastos. Além disso, foi observado que o alendronato inibe a função apresentadora de antígeno dos macrófagos, provavelmente por meio da inibição da produção de IL-1, o que poderia contribuir para o efeito inibitório da droga na reabsorção óssea (Sansoni et al., 1995).

Estudos têm mostrado que os BFs podem afetar a reabsorção óssea mediada por osteoclastos de várias maneiras, incluindo efeitos no recrutamento, diferenciação e atividade reabsortiva dessas células, podendo também induzir apoptose (Fleish, 2002; Russell, 2007).

Durante a reabsorção óssea, os BFs incorporados ao osso são liberados nas lacunas de Howship e internalizados nos clastos por endocitose, afetando-os diretamente. Assim, os clastos perdem sua borda ativa pregueada e inicia-se a quebra do seu citoesqueleto, desmobilizando a atividade celular reabsortiva e entrando em morte celular programada (apoptose) (Russell e Rogers, 1999; Martins-Ortiz, 2004).

Tendo em vista que os osteoclastos, multinucleados e maduros, são formados pela fusão de precursores mononucleares de origem hematopoiética, os BFs poderiam também inibir a reabsorção óssea prevenindo a formação dos osteoclastos e, também, afetando a sua maturação (Russell, 2007).

Alguns dos mecanismos moleculares de ação dos BFs têm sido elucidados recentemente. Dependendo da presença de um átomo de nitrogênio na cadeia alquílica da molécula, os BFs agem sendo tóxicos aos osteoclastos ou interferindo com vias intracelulares específicas no interior das células osteoclásticas (Massa et al., 2006). O primeiro grupo de BFs compreende aqueles que não contêm nitrogênio, como o etidronato, o clodronato e o 
tiludronato, os quais são convertidos, no meio intracelular, em análogos citotóxicos de adenosina-trifosfato (ATP), por reverter reações envolvidas na ativação de aminoácidos durante a síntese protéica, resultando em nucleotídeos não-hidrolisáveis (AppCp). O acúmulo intracelular destes metabólitos causa inibição das funções osteoclásticas e pode induzir a apoptose destas células, constituindo o principal modo de ação deste grupo de BFs (Russell et al., 2008).

Por outro lado, o segundo grupo contém os mais potentes BFs aminados, como o pamidronato, o alendronato, o ibandronato, o risedronato e o zoledronato. Os membros deste grupo interferem com outras reações metabólicas, notadamente na via biossintética do mevalonato, bem conhecida pelo seu papel na biossíntese do colesterol e de outros esteróis. Sabe-se que o principal alvo é a enzima farnesil pirofosfato sintase (FPPS), a qual é inibida por todos os bisfosfonatos aminados usados clinicamente. A FPPS está presente em peroxissomos, mas também nas mitocôndrias e no citosol, sendo que o local de ação desses BFs permanece desconhecido. A inibição da FPPS bloqueia a síntese da farnesil pirofosfato (FPP), o que reduz a concentração desse substrato necessário para a geranilgeranil pirofosfato (GGPP) sintase produzir GGPP. Tanto a FPP como a GGPP (lipídeos isoprenóides) são metabólitos requeridos para a prenilação (modificação lipídica) de pequenas proteínas que se ligam ao GTP (pequenas GTPases), que são responsáveis pela integridade do citoesqueleto e pela sinalização intracelular (Fleish, 2002; Massa et al., 2006; Russell, 2007; Ghoneima et al., 2010).

O alendronato de sódio, um aminobisfosfonato desenvolvido recentemente, é um composto capaz de ligar-se aos cristais de hidroxiapatita no osso e unir-se, preferencialmente, às superfícies ósseas reabsorvidas, particularmente àquelas que estão sofrendo atividade de reabsorção osteoclástica (Reid, 2003). A afinidade do alendronato por fosfato de cálcio e sua forte ligação à hidroxiapatita leva a uma rápida incorporação ao esqueleto, estimando-se que seu tempo de vida seja entre 1 e 10 anos, variando em diferentes espécies e dependendo do índice de turnover ósseo (Orbak et al., 2006).

Embora o mecanismo de ação do alendronato sódico seja principalmente avaliado no tecido ósseo (Bone et al., 1997; Rosen et al., 2005; Silverman et al., 2007; Inoue et al., 2008; Okada et al., 2008), pouco se sabe sobre seus efeitos na formação dos tecidos dentários mineralizados, incluindo esmalte e dentina.

Uma vez que esta droga também é indicada na terapia de diversas desordens ósseas pediátricas, como osteopororose infantil, osteogênese imperfeita, intoxicação por vitamina $D$, hiperparatireoidismo primário, hipercalcemia e hipercalciúria (Srivastava e Alon, 2003; Orbak et al., 2006; Freundlich e Alon, 2008; Inoue et al., 2008; Bachrach e Ward, 2009; Atas et al., 
2009; Leanne et al., 2009), é possível que a administração de alendronato sódico a crianças ou adolescentes, nos quais a odontogênese e/ou erupção dentária está ocorrendo, possa induzir alterações estruturais dos elementos dentais, benéficas ou maléficas, ou mesmo falha no processo eruptivo (Bradaschia-Correa et al., 2007).

Alguns autores têm evidenciado que a administração de BFs não aminados em elevadas e sucessivas doses afeta a mineralização, tanto da dentina quanto do esmalte (Simmelink, 1987; Ohya et al., 1989; Fejerskov et al., 1990; Weile et al., 1990; 1993; Fouda et al., 1991; Takano et al., 1998). Estudos microscópicos em ratos demonstraram que o tratamento com alguns BFs, como o etidronato, interfere na amelogênese, ocasionando distúrbios nos ameloblastos e, consequentemente, no desenvolvimento do esmalte, incluindo hipomineralização e formação de cistos subameloblásticos (Simmelink, 1987; Fouda et al., 1989; 1991; 1992; Fejerskov et al., 1990).

Segundo Massa et al. (2006), o principal efeito do alendronato na estrutura dentária é romper o equilíbrio de secreção/degradação de amelogenina na matriz de esmalte, que é controlado pelos ameloblastos durante o estágio secretório da amelogênese. Embora os achados sugiram que as moléculas desta proteína tenham sido secretadas em excesso pelos ameloblastos, é possível que elas possam ter sido insuficientemente degradadas, durante o período secretório da amelogênese.

É reconhecido que, além dos efeitos antiosteoclastos bem conhecidos dos BFs, este grupo de drogas apresenta propriedades físico-químicas dose-dependentes (Baumann et al., 1978), que interferem com a transformação de fosfato de cálcio amorfo em hidroxiapatita (Fleish, 1998). Por outro lado, os BFs também exercem efeitos na formação da matriz, os quais podem ocasionar distúrbios na mineralização (van den Bos e Beertsen, 1987; Ogawa et al., 1989).

De fato, várias alterações foram relatadas com relação à hipomineralização de esmalte e dentina em incisivos de ratos induzida pela administração de etidronato (1hidroxietilideno-1,1-bisfosfonato ou HEBP): a inibição da mineralização da dentina, subsequentemente, promove defeito na secreção e deposição protéica do esmalte, resultando em evidentes zonas livres de esmalte que interrompem a continuidade de sua camada (Ogawa et al., 1989).

Foi relatado também que ratos injetados com etidronato (HEBP) $(8 \mathrm{mgP} / \mathrm{Kg} / \mathrm{dia})$, por 7 dias, desenvolveram hipoplasia de esmalte, devido a um distúrbio na secreção de proteínas (Fuangtharnthip et al., 2000; Yamada et al., 2000).

No entanto, atualmente, o alendronato de sódio ou os bisfosfonatos aminados em geral são clinicamente mais indicados para tratamento de desordens ósseas que o etidronato 
(Orbak et al., 2006; Inoue et al., 2008; Lewiecki, 2010; Kawate et al., 2010), justificando a necessidade de estudos para avaliar se a incorporação desse medicamento na estrutura do esmalte e/ou da dentina poderia ocasionar alterações morfológicas e estruturais, aumentando a sua microdureza e, consequentemente, elevando a resistência à cárie dental, ou poderia ocasionar o desenvolvimento de anomalias de estrutura, reduzindo a resistência à cárie dental. 
Proposição 


\section{PROPOSIÇÃo}

Os objetivos do presente estudo foram avaliar, in vivo, o efeito do uso sistêmico do alendronato sódico:

- Na densidade mineral óssea da metáfise proximal da tíbia de ratos, por meio da densitometria óptica radiográfica e da técnica de absortometria radiológica de dupla energia (DXA).

- Nas estruturas dentárias mineralizadas de incisivos de ratos, por meio da espectrometria na região do infravermelho, espectroscopia de fluorescência, microdureza transversal, microscopia eletrônica de varredura e microscopia de luz polarizada. 
Materiale Métodos 


\section{Material e Métodos}

O projeto de pesquisa foi previamente submetido à apreciação pelo Comitê de Ética para o Uso de Animais em Pesquisa da Universidade de São Paulo/Campus de Ribeirão Preto (Protocolo no 10.1.468.53.5), tendo sido aprovado (Anexo A).

\section{Teste de Solubilidade do Alendronato de Sódio}

Primeiramente, a massa inicial do alendronato de sódio quimicamente puro $(2,0 \mathrm{~g})$ (Alendronato Monossódico Triidratado, Galena Química e Farmecêutica Ltda, Índia) foi pesada empregando balança de precisão (Ohaus Adventurer ${ }^{\mathrm{TM}} \mathrm{SL}$, Alemanha) . Em seguida, foram adicionados $2 \mathrm{~mL}$ de água destilada em um Becker, com auxílio de uma pipeta LABMATE $^{+\circledR}$ (Biosystems, Curitiba, PR, Brasil), juntamente com barra magnética, sendo esse conjunto colocado no agitador magnético Speedsafe ${ }^{T M}$ (HANNA Intruments ${ }^{\circledR}$ Brasil). O alendronato sódico foi adicionado aos poucos e agitado até que fosse completamente solubilizado. Quando a solução tornou-se saturada, sem solubilização do alendronato, observou-se a formação de um precipitado, sendo a solução filtrada nesse momento. Essa massa foi medida e somada com a massa restante do alendronato que não havia sido adicionado e, então, subtraída da massa inicial, para que fosse calculada a quantidade de alendronato solubilizada no volume inicial de água destilada. Este teste foi realizado em triplicata. A média dos três valores obtidos foi de $33,75 \mathrm{mg}$ de alendronato de sódio por $\mathrm{mL}$ de água destilada, à temperatura de, aproximadamente, $28^{\circ} \mathrm{C}$.

Este teste foi realizado para determinar a quantidade máxima de alendronato sódico que poderia ser solubilizada em água destilada, para garantir que toda a massa do medicamento estivesse solubilizada na solução a ser administrada aos animais.

\section{Animais}

Para a realização da pesquisa, foram utilizados 45 ratos albinos da linhagem Wistar (Rattus norvegicus), machos, com 36-42 dias de idade, pesando em média 200-230g. Durante todo o experimento, os animais foram mantidos no Biotério convencional da Faculdade de Odontologia de Ribeirão Preto, recebendo os cuidados de rotina. Os animais permaneceram em caixas grandes (4 ratos por caixa) em ambiente com umidade natural e temperatura local mantida a $24 \pm 0,5^{\circ} \mathrm{C}$, controlada por condicionador de ar quente/frio. $\mathrm{A}$ iluminação foi automatizada, controlada por timer, com ciclo de 12 horas claro/12 horas escuro. Os animais receberam ração e água filtrada à vontade e foram divididos em 2 grupos: 
1) Grupo experimental: constituído por 25 animais submetidos à medicação com alendronato sódico; e

2) Grupo controle: constituído por 20 animais que receberam apenas água destilada (veículo).

\section{Administração do Alendronato de Sódio (Grupo Experimental) e da Água Destilada (Grupo Controle) e Determinação do Peso Corporal dos Animais}

Considerando que o índice metabólico de murinos apresenta-se duas vezes maior que o de humanos (Keidel, 1971), foram administradas duas doses semanais de $1 \mathrm{mg} / \mathrm{Kg}$ de alendronato de sódio (Alendronato Monossódico Triidratado, Galena Química e Farmecêutica Ltda, Índia) quimicamente puro diluído em água destilada, via gavagem (sonda inserida via bucal), no volume de $0,3 \mathrm{~mL}$, durante um período de 60 dias, enquanto que os animais do grupo controle receberam apenas água destilada. Este procedimento foi realizado no período da manhã (9 horas), às terças e sextas-feiras. Para a administração da droga ou da água destilada via gavagem, os animais foram contidos manualmente. Foi utilizada uma sonda descartável siliconizada (sonda gástrica Levine, Mark Med Industria e Comércio Ltda, Bragança Paulista-SP, Brasil) número 6, com 3 centímetros de comprimento, acoplada a uma seringa descartável de $1 \mathrm{~mL}$ (seringa de insulina Injex Indústrias Cirúrgicas Ltda, Ourinhos-SP, Brasil), para que a solução fosse injetada diretamente no trato gastrointestinal.

Semanalmente, os animais foram pesados em balança eletrônica (Modelo 3400, ๑Toledo do Brasil) para controle do peso corporal e para que uma nova solução de alendronato fosse preparada com a concentração adequada, de acordo com a média do peso obtida, ajustando a dose de alendronato ao peso dos animais, a cada semana. Tendo em vista que a média do peso inicial dos animais foi de $0,215 \mathrm{Kg}$ e a média do peso final foi de $0,448 \mathrm{Kg}$, o estudo foi iniciado com a dose de 0,215 mg de alendronato de sódio em 0,3mL de água destilada, a cada administração, e concluído com a dose de 0,448 mg de alendronato de sódio em $0,3 \mathrm{~mL}$ de água destilada.

A sequência da metodologia empregada para determinação do peso corporal dos animais e administração do alendronato sódico ou da água destilada encontra-se ilustrada no fluxograma 1. 


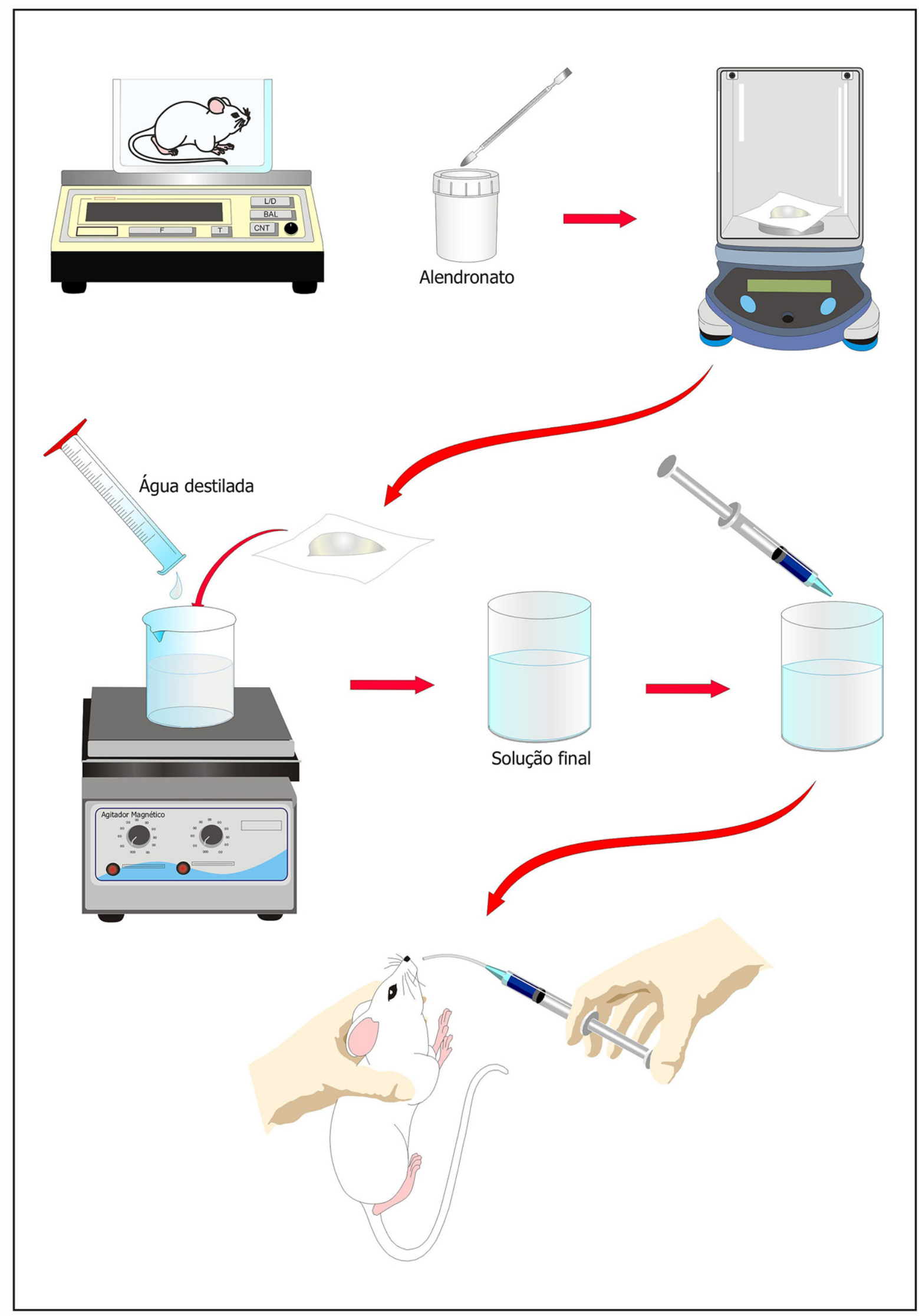

Fluxograma 1. Metodologia empregada para a determinação do peso corporal dos animais e administração do alendronato sódico. 


\section{Obtenção das Amostras}

Decorrido o período de 60 dias, os animais foram mortos por sobredose anestésica, por meio do uso de associação de ketamina $(300 \mathrm{mg} / \mathrm{Kg})$ e xilasina $(30 \mathrm{mg} / \mathrm{Kg}$ ) e, em seguida, foram extraídos os incisivos superiores e removidas as tíbias.

As tíbias foram submetidas à avaliação da densidade mineral óssea por meio de análise radiográfica e da técnica de absortometria radiológica de dupla energia (DXA).

Os incisivos superiores foram submetidos às seguintes avaliações:

- Análise química do elemento dental, a fim de verificar se houve incorporação do alendronato sódico nos tecidos mineralizados.

- Microdureza transversal, para análise da microdureza superficial do esmalte e da dentina.

- Microscopia eletrônica de varredura e microscopia de luz polarizada, para analisar eventuais alterações na superfície e em profundidade, na estrutura dentária.

O delineamento experimental foi realizado com o auxílio do programa SAS (Statistical Analysis System) for Windows versão 9.1.3 (SAS Institute Inc, Cary, NC, USA), com o objetivo de aleatorizar as amostras, determinando quais incisivos superiores (direito ou esquerdo) e quais tíbias (direita ou esquerda) de cada animal seriam submetidos às diferentes análises.

\subsection{Análise da Densidade Mineral Óssea Radiográfica e por meio da Técnica de Absortometria Radiológica de Dupla Energia (DXA)}

As tíbias recém-removidas dos grupos experimental e controle foram dissecadas, limpas, envolvidas em gazes umedecidas com soro fisiológico e armazenadas em freezer à temperatura de $-20^{\circ} \mathrm{C}$. Para as análises, os ossos foram retirados do freezer com antecedência de 12 horas e colocados em geladeira à temperatura média de $4^{\circ} \mathrm{C}$, para descongelamento gradual (Cecim, 2007).

A análise da densidade mineral óssea foi realizada, primeiramente, pelo método da Densitometria Óptica Radiográfica (Oliveira et al., 2006; Cecim, 2007). Um total de 16 tíbias do grupo experimental e 10 do grupo controle, aleatorizadas de acordo com o delineamento experimental, foram posicionadas de maneira simétrica no filme e radiografadas em incidência ântero-posterior, juntamente com um referencial densitométrico formado por uma escala de liga de alumínio (liga 6063 ABNT) de 8 degraus de 0,5mm de altura cada um (Figura 1). 


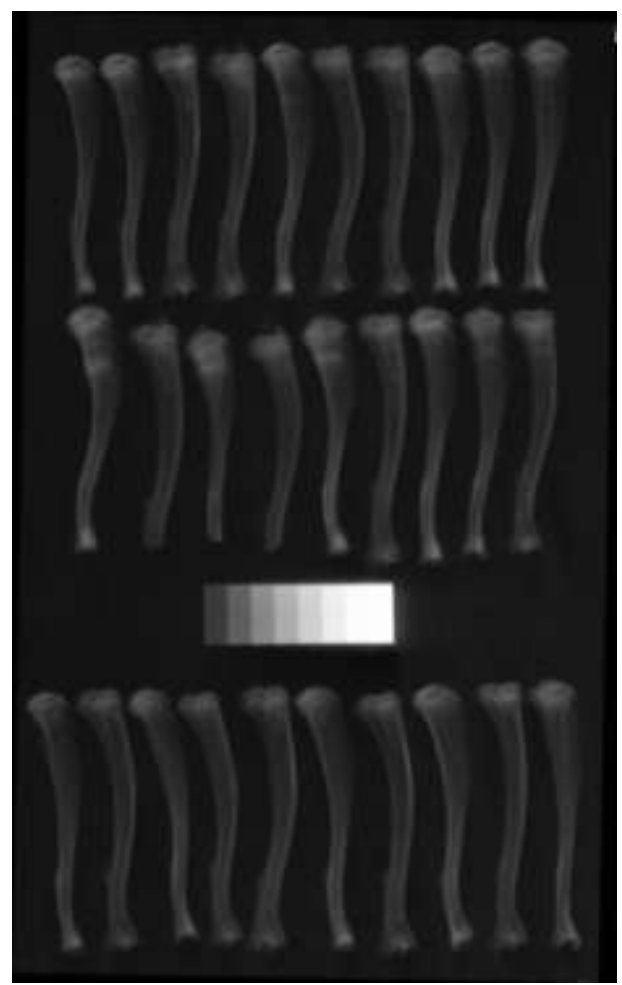

Figura 1. Radiografia das tíbias posicionadas simetricamente para a análise da Densitometria Óptica Radiográfica.

As radiografias foram realizadas com aparelho de raio-X The Weber Dental MFG (Ohio, U.S.A), no "Laboratório de Análises e Controle de Imagem Radiográfica Odontológica (LACIRO)" da Faculdade de Odontologia de Ribeirão Preto - USP, com distância foco-filme de 1,0 m e ajustado para exposição de $60 \mathrm{kVp}$ e $10 \mathrm{~mA}$, por 0,6 segundos. Foram utilizados filmes radiográficos de mamografia $\left(18 \mathrm{~cm} \times 24 \mathrm{~cm}\right.$ ) Kodak ${ }^{\circledR}$ Min-R S (Kodak Brasileira Com. Ind. Ltda) e chassi com Ecran médio. O tempo de processamento foi de 2 minutos no revelador $\left(27^{\circ} \mathrm{C}\right), 30$ segundos no enxágüe intermediário, 4 minutos no fixador e 10 minutos no enxágüe final.

Foram obtidas três radiografias, as quais foram digitalizadas em um scanner profissional (Epson modelo - Expression $636^{\circledR}$ ) controlado pelo programa de computador Epson scanner II 32, versão $2,10 \mathrm{E}^{\circledR}$. Foi utilizado como fonte de documento TPU for Pos. Film, tipo de imagem black and white photo, resolução de 600 pixels/polegada ou 236,22 pixels/cm e o destino screen (general). As imagens foram armazenadas no formato TIFF (Tagged Image File Format).

Para a análise das imagens radiográficas foi utilizado o histograma da intensidade das escalas de tons no "canal luminosidade" do programa de computador Adobe Photoshop 7.0.1. (Adobe Systems Incorporated, U.S.A). O eixo horizontal do histograma representa os valores ou níveis de intensidade, do mais escuro (0), que se localiza na extremidade esquerda, ao mais claro (255), na extremidade direita, e o eixo vertical representa o número 
de "pixels". Desta forma, obteve-se um gráfico da escala de tons da imagem e o tipo de registro da imagem, de forma que uma imagem de registro baixo contém detalhes concentrados nas áreas radiolúcidas e uma imagem de registro alto contém detalhes concentrados nas áreas mais radiopacas (Cecim, 2007).

A área selecionada para obter o valor médio de intensidade de luminosidade foi a metáfise proximal da tíbia, conforme preconizado na maior parte dos estudos de biologia óssea (Breen et al., 1998; Schmidt et al., 2003; Kansaki et al., 2009; Xu et al., 2010). Após a mensuração de cada espécime das três radiografias, foi obtida a média de densidade mineral óssea (BMD), com auxílio do programa Microsoft Office Excel 2003 (Microsoft Corporation, U.S.A) para cada grupo (experimental e controle).

Após as tíbias terem sido utilizadas para esta análise, foram transferidas para tubos Falcon contendo PBS, devidamente vedados, e avaliadas por meio do Densitômetro de Absorbância de Raios-X de Energia Dual Lunar PIXImus (Lunar PIXImus Corp. Headquarters, Madison, WI, USA), para registro da Densidade Mineral Óssea (BMD) da metáfise proximal, em $\mathrm{g} / \mathrm{cm}^{2}$ (Xu et al., 2010; Silva, 2010). Os dados obtidos foram registrados e analisados pelo software Lunar PIXImus, versão 2.2 (Lunar PIXImus Corp. Headquarters) (Figura 2). Essa análise foi efetuada na Medical School - Harvard University - EUA.

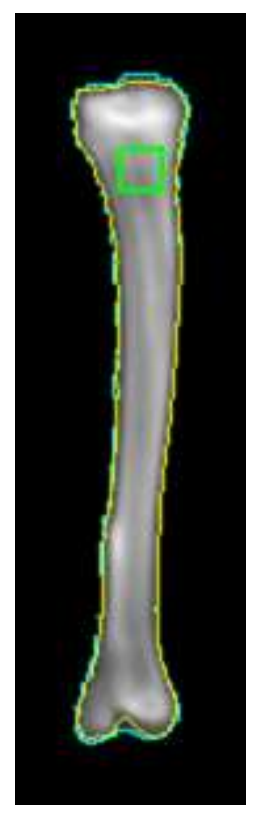

Figura 2. Registro da Densidade Mineral Óssea (BMD) da metáfise proximal da tíbia por meio do Densitômetro de Absorbância de Raios-X de Energia Dual.

Os resultados da densidade mineral óssea obtidos pelo método radiográfico e pela técnica de absortometria radiológica de dupla energia (DXA) foram analisados por meio do teste não-paramétrico de Kruskal-Wallis, utilizando o software SAS (Statistical Analysis System) for Windows versão 9.1.3 (SAS Institute Inc. Cary, NC, USA). O nível de significância adotado foi de $5 \%$. 


\subsection{Análise Química Qualitativa da Incorporação do Alendronato Sódico nas Estruturas Dentárias Mineralizadas (Esmalte e Dentina) por Espectrometria na Região do Infravermelho}

A presença ou não de alendronato incorporado no elemento dental foi analisada com base no espectro de infravermelho por Transformada de Fourier (FT-IR) (Maranho et al., 2009). Para realizar a comparação entre os dentes do grupo controle e do grupo experimental, um incisivo superior de cada grupo, os quais foram adequadamente limpos e armazenados em freezer à temperatura de $-20^{\circ} \mathrm{C}$, foi submetido à análise qualitativa por espectrometria no infravermelho.

A radiação infravermelha não apresenta energia suficiente para excitar os elétrons e provocar transições eletrônicas, mas faz com que os átomos ou grupos de átomos vibrem com maior rapidez e com maior amplitude em torno das ligações covalentes que os unem. Quando a ligação absorve energia, sofre alterações e, ao retornar ao estado original, libera essa energia que é detectada pelo espectrofotômetro (Maranho et al., 2009).

Para a realização da análise, a amostra foi obtida raspando-se o esmalte e a dentina coronária de um incisivo de cada grupo (experimental e controle), com auxílio de uma lâmina de bisturi, obtendo o pó da estrutura dentária mineralizada. As amostras foram preparadas no estado sólido, utilizando pastilha de brometo de potássio (KBr). Os espectros na região do infravermelho foram obtidos com o Espectrofotômetro IR Prestige-21 Shimadzu (Shimadzu, Kyoto, Japan).

Os resultados foram avaliados por um pesquisador experiente através da comparação dos espectros na região do infravermelho obtidos das amostras dos dentes de cada grupo (experimental e controle) e da amostra de alendronato sódico apenas.

A sequência da metodologia empregada para análise química qualitativa da incorporação do alendronato sódico nas estruturas dentárias, por espectrometria na região do infravermelho, encontra-se ilustrada no fluxograma 2. 


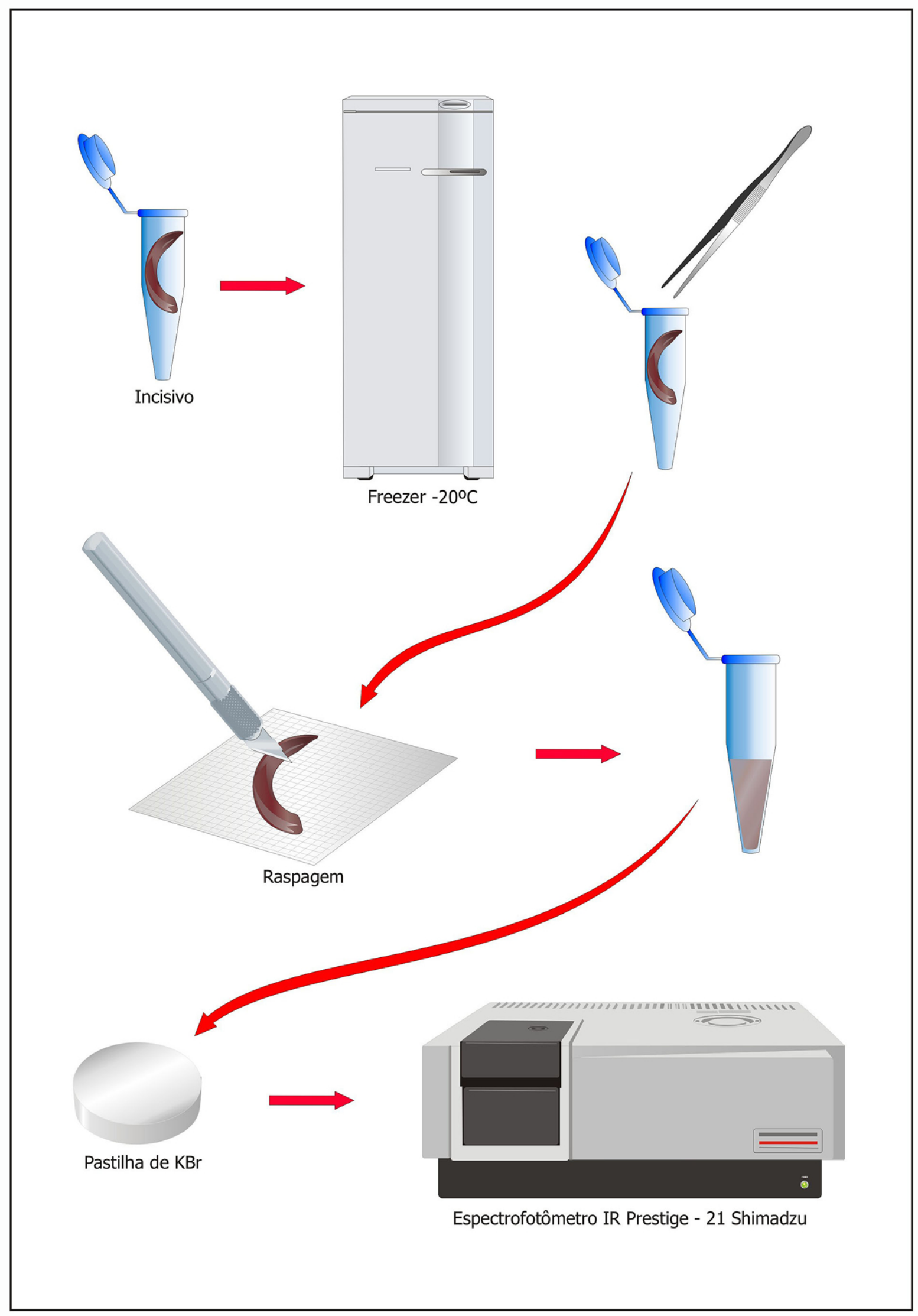

Fluxograma 2. Metodologia empregada para a análise química qualitativa da incorporação do alendronato sódico nas estruturas dentárias, por espectrometria na região do infravermelho. 


\subsection{Análise Química Quantitativa da Incorporação do Alendronato Sódico nas Estruturas Dentárias por Espectroscopia de Fluorescência}

Incisivos superiores recém-extraídos ( $113 \mathrm{mg}$ ) foram adequadamente limpos e armazenados em freezer, à temperatura de $-20^{\circ} \mathrm{C}$, até que fossem submetidos à análise por espectroscopia de fluorescência, a qual foi realizada com base no método descrito por De Marco et al. (1989).

Previamente à análise, foi necessário que cada elemento dental fosse macerado, com o auxílio de um grau e pistilo de cerâmica, para aumentar a superfície de contato com a solução. O número de amostras analisadas em cada grupo foi igual a 3, totalizando 9 dentes por grupo (experimental e controle), tendo em vista que o estudo foi realizado em triplicata.

A maioria dos bisfosfonatos não apresenta propriedades cromóforas, com exceção de alguns compostos como o tiludronato, que possui anel aromático em sua estrutura. Sendo assim, o alendronato necessita ser submetido previamente a uma reação de derivatização com 9-fluorenilmetil-cloroformato (FMOC) (Figura 3), a qual tem como objetivo conferir ao composto a capacidade de absorver radiação ultravioleta ou de emitir fluorescência (Ribeiro e Volpato, 2005).

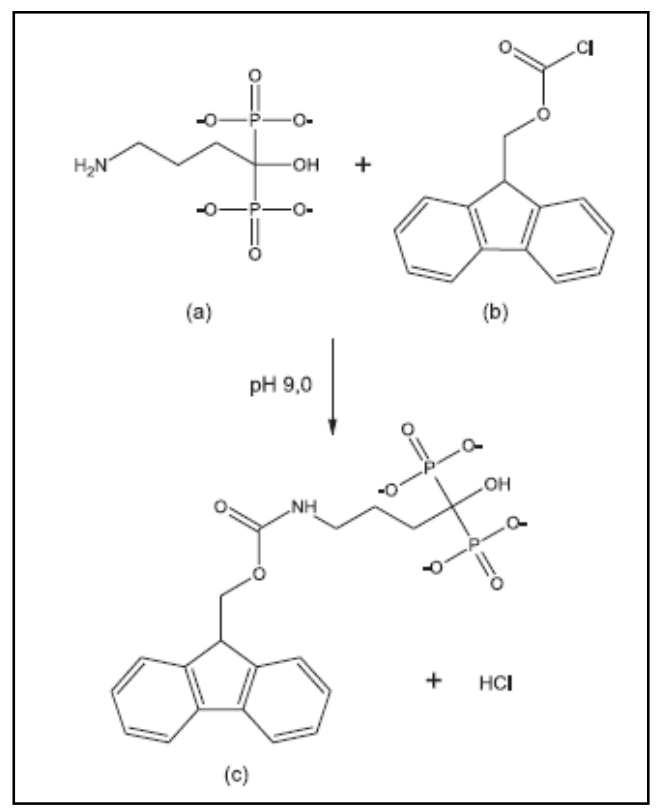

Figura 3. Reação de derivatização do alendronato (a) com 9-fluorenimetil-cloroformato (FMOC) (b), originando produto cromóforo (c). Adaptado de De Marco et al. (1989). 
O preparo das soluções contendo os reagentes necessários para a reação de derivatização (De Marco et al., 1989) foi realizado da seguinte maneira:

1) Alendronato sódico (Galena Química e Farmecêutica Ltda, Índia): $21,5 \mathrm{mg}$ ou $0,0215 \mathrm{~g}$ em $250 \mathrm{~mL}$ de água destilada;

2) 9-fluorenilmetil-cloroformato (Sigma-Aldrich Brasil Ltda) (FMOC; 0,5\%): 50 $\mathrm{mg}$ ou $0,05 \mathrm{~g}$ em $100 \mathrm{~mL}$ de acetonitrila;

3) Borato de sódio (Sigma-Aldrich Brasil Ltda) (0,1 mol/L): 5,025 g em $250 \mathrm{~mL}$ de água destilada;

4) Citrato de sódio (Sigma-Aldrich Brasil Ltda) (0,1 mol/L): 7,35 g em $250 \mathrm{~mL}$ de água destilada.

Reação de Derivatização e Curva de Calibração do Alendronato Sódico

Primeiramente foi construída uma curva de calibração do alendronato sódico. Para este procedimento adicionou-se 10,$0 ; 20,0 ; 30,0$ e $40,0 \mathrm{~mL}$ da solução de alendronato $(0,086 \mathrm{mg}$ por $\mathrm{mL})$ separadamente, em balões volumétricos. Em seguida, foram acrescentados em cada recipiente $5,0 \mathrm{~mL}$ da solução de citrato de sódio, 5,0 mL da solução de borato de sódio e 4,0 mL da solução de 9-fluorenilmetil-cloroformato (FMOC). Cada solução foi agitada por 30 segundos e, após 30 minutos de espera para a reação, foram adicionados $25 \mathrm{~mL}$ de diclorometano, etapa necessária para extrair o excesso do reagente FMOC. O diclorometano permite que a fase aquosa contendo o fármaco derivatizado permaneça na parte superior, devido à sua menor densidade facilitando, assim, a coleta (Ribeiro e Volpato, 2005). Posteriormente, os balões com cada solução foram agitados novamente em vortex por 30 segundos, deixados em repouso por 5 minutos e, então, centrifugados a $1000 \mathrm{rpm}$ por 5 minutos para remover o excesso de reagente. A porção superior da fase aquosa de cada amostra foi removida, com o auxílio de uma pipeta, e transferida para outro frasco para realizar a leitura, sendo as amostras excitadas em $266 \mathrm{~nm}$, com espectro de emissão em $315 \mathrm{~nm}$.

\section{Processamento dos Amostras}

Cada amostra contendo três incisivos superiores murinos devidamente triturados foi colocada em um Becker contendo $5 \mathrm{~mL}$ da solução de borato de sódio sob agitação em agitador magnético, durante um período de 24 horas, para que fosse extraído o alendronato 
que possivelmente pudesse ter sido incorporado à estrutura dentária durante a sua mineralização. Em seguida, a solução remanescente de cada amostra foi removida, sem qualquer resíduo e, em seguida, transferida para um balão, ao qual adicionou-se $5,0 \mathrm{~mL}$ da solução de citrato de sódio e $4,0 \mathrm{~mL}$ da solução de FMOC. A solução foi agitada por 30 segundos e, após 30 minutos de espera para a reação, foram adicionados $25 \mathrm{~mL}$ de diclorometano. Posteriormente, o balão com a solução foi agitado novamente em vortex por 30 segundos, deixado em repouso por 5 minutos e, então, centrifugado a 1000 rpm por 5 minutos para remover o excesso de reagente. A porção superior da fase aquosa de cada amostra foi removida, com o auxílio de uma pipeta, e transferida para outro frasco para realizar a leitura. O derivado de Alendronato/FMOC formado após a reação possui luminescência quando excitado em $266 \mathrm{~nm}$.

Os espectros de excitação e emissão do derivado de alendronato/FMOC foram realizados no Espectrofluorômetro Shimadzu RF-5301PC Series (Shimadzu, Kyoto, Japan), equipado com lâmpada Xenon 150W/Ozone free.

Os resultados foram avaliados por um pesquisador experiente através da análise dos espectros obtidos, determinando a porcentagem de alendronato incorporado no elemento dental (quantidade de alendronato por peso de cada dente).

A sequência da metodologia empregada para a análise química quantitativa da incorporação do alendronato sódico nas estruturas dentárias, por espectroscopia de fluorescência, encontra-se ilustrada no fluxograma 3. 


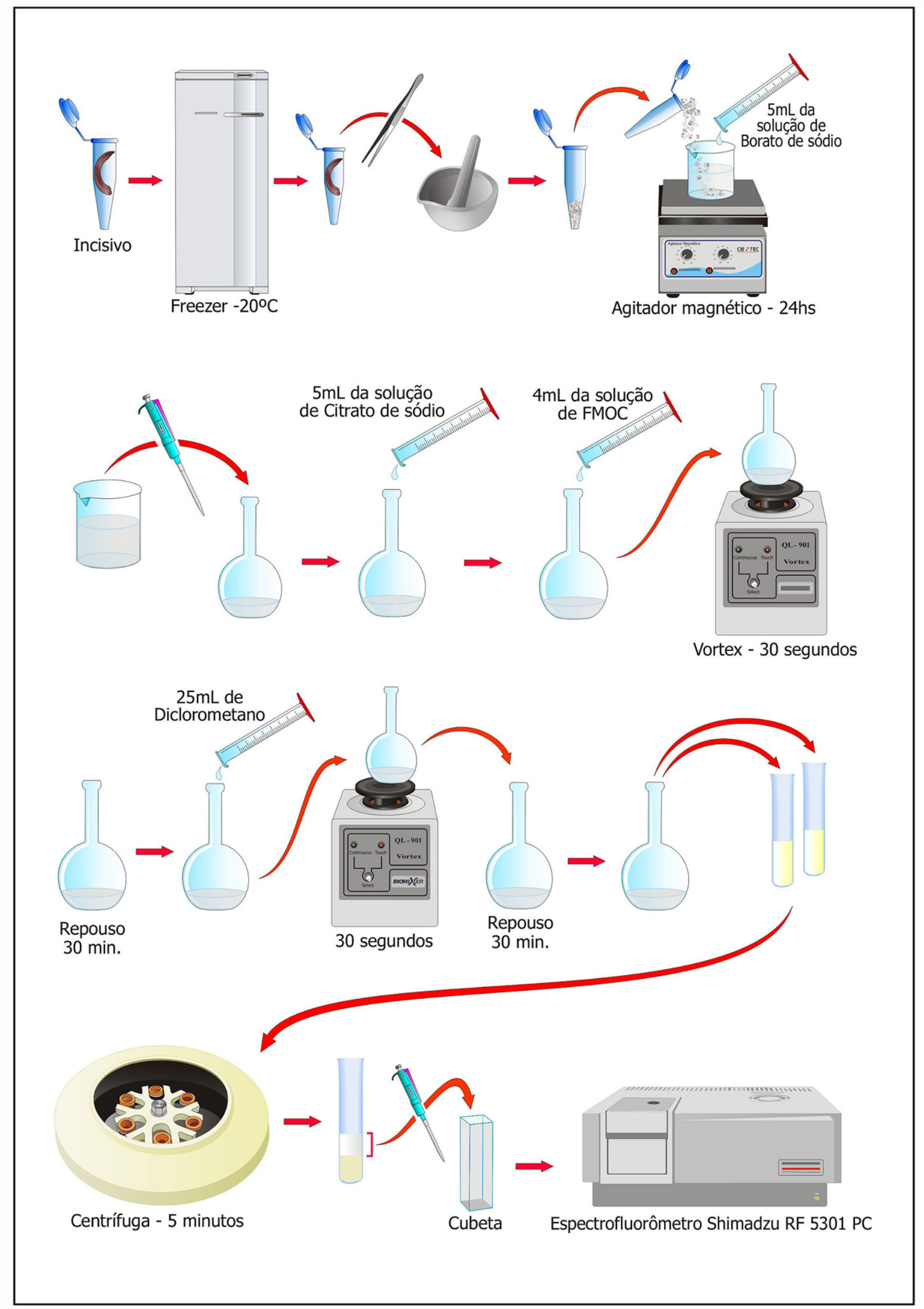

Fluxograma 3. Metodologia empregada para a análise química quantitativa da incorporação do alendronato sódico nas estruturas dentárias, por espectroscopia de fluorescência. 


\subsection{Avaliação do Efeito da Incorporação do Alendronato Sódico nas Estruturas Dentárias Mineralizadas}

\section{Análise da Microdureza Transversal}

Um total de 32 incisivos superiores (20 do grupo experimental e 12 do grupo controle), recém-extraídos dos ratos, foram limpos para a remoção de remanescentes teciduais, envoltos por gase umedecida com água destilada, individualmente, e armazenados em frascos plásticos em geladeira a temperatura de $4^{\circ} \mathrm{C}$, sendo mantidos em umidade relativa.

Para preparar os espécimes, os dentes foram posicionados em uma lâmina de cera rosa 7 (Wilson-Polidental, Cotia, Brasil), com a superfície mesial voltada para a cera. Os incisivos foram colocados no interior de tubos de PVC de $3 / 4$ de polegada com $1 \mathrm{~cm}$ de altura e 1,5 cm de diâmetro, os quais foram, em seguida, preenchidos com resina de poliéster quimicamente ativada Mioflex ${ }^{\circledR}$ (Mioflex General Tintas e Vernizes Ltda, Jandira-SP, Brasil). Após a polimerização da resina, os tubos de PVC foram removidos e os espécimes foram então planificados com lixas d'água de granulação decrescente (600 e 1200) ( ${ }^{\odot}$ Norton Abrasivos, Brasil) até a exposição da dentina, empregando uma politriz (Struers $A / S$, Copenhagen, Denmark), sob refrigeração com água. Posteriormente, foram polidos com pasta abrasiva de alumina (granulação 0.3um) (Alpha and Gamma Micropolish, Buehler, Lake Bluff, IL, USA) e disco de feltro, sob refrigeração com água. Em seguida, os espécimes foram lavados com água deionizada, submetidos ao ultra-som por 10 minutos em água deionizada e novamente armazenados em $100 \%$ de umidade relativa (gase umedecida com água destilada mantida em frascos plásticos) (Rehder Neto, 2008).

Para a análise da microdureza transversal foi utilizado o microdurômetro Shimadzu HMV-2 (Shimadzu, Kyoto, Japan) e penetrador Knoop, onde as leituras foram mensuradas com o auxílio de um software específico (New Age, Software Cams do Sul Ampton, PA, E.U.A.) A carga estática e tempos aplicados foram de 25 gramas por 10 segundos para esmalte e de 10 gramas por 10 segundos para dentina (Rehder Neto, 2008).

Tendo como base a análise da microdureza efetuada em esmalte dental de dentes de ratos por Vieira et al. (2005), cinco indentações foram realizadas na porção central do esmalte em relação à distância entre a superfície externa e a junção amelo-dentinária (JAD), onde cada indentação foi espaçada $200 \mu \mathrm{m}$ uma da outra. Em dentina, também baseado na metodologia descrita por Vieira et al. (2005), foram escolhidos dois níveis de profundidade (100 $\mu \mathrm{m}$ e $300 \mu \mathrm{m}$ da JAD), sendo realizadas cinco mensurações em cada profundidade, distanciadas $200 \mu \mathrm{m}$ umas das outras (Figura 4). 


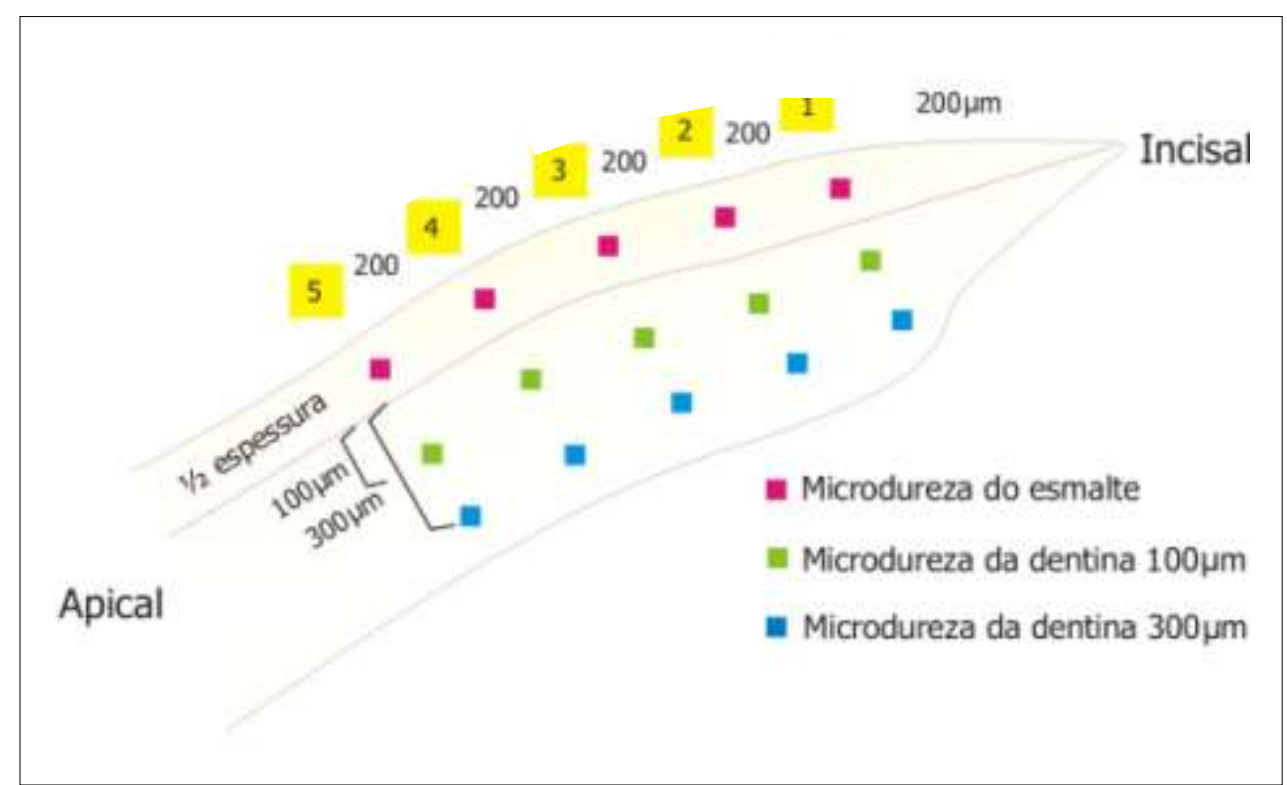

Figura 4. Esquema de incisivo de rato, evidenciando os locais onde as indentações foram realizadas. (Adaptado de Vieira et al., 2005).

Os resultados obtidos foram analisados por meio do teste não-paramétrico de Kruskal-Wallis, utilizando o software SAS (Statistical Analysis System) for Windows versão 9.1.3 (SAS Institute Inc. Cary, NC, USA). O nível de significância adotado foi de 5\%.

A sequência da metodologia empregada para análise da microdureza transversal encontra-se ilustrada no fluxograma 4. 


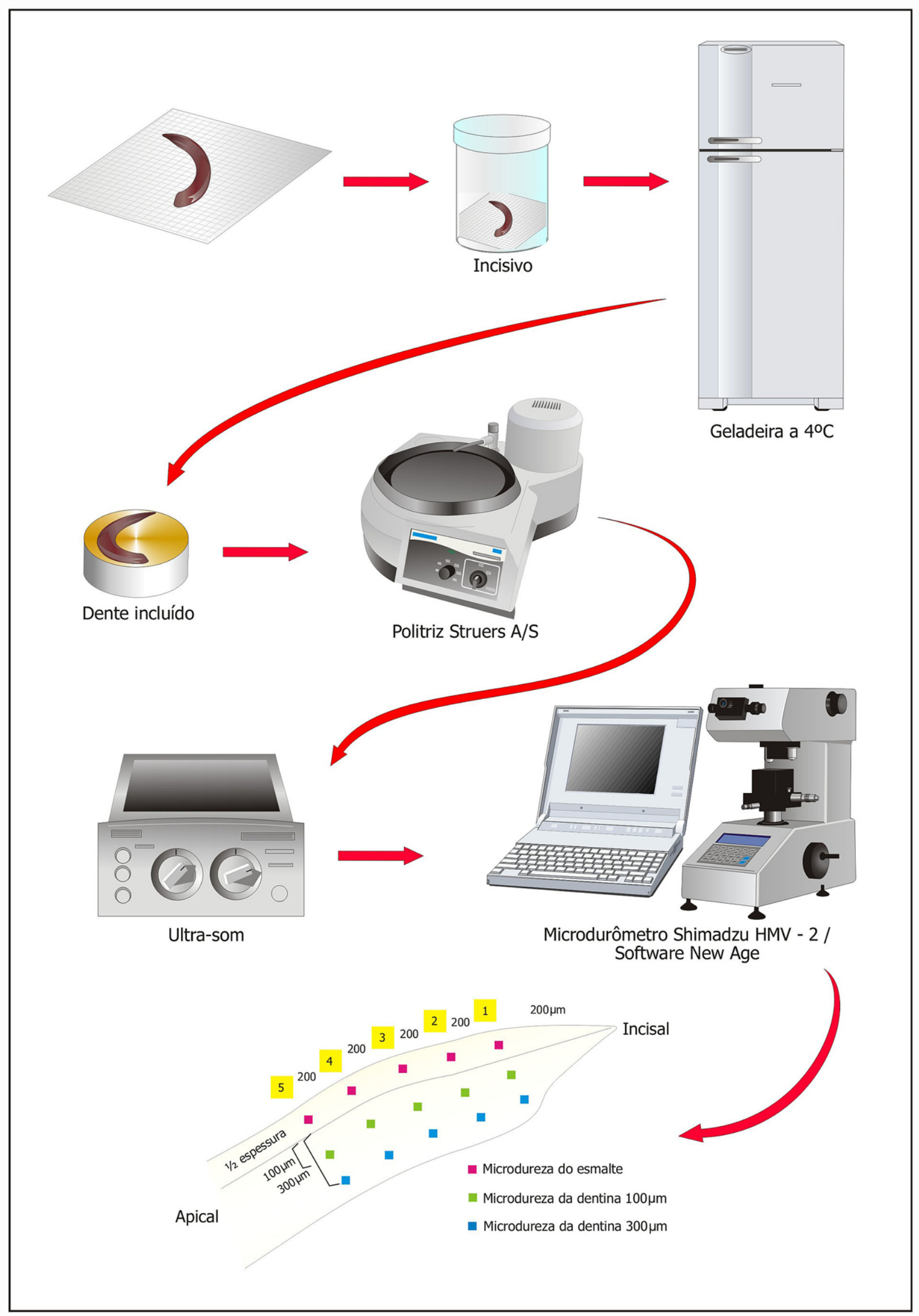

Fluxograma 4. Metodologia empregada para a análise da microdureza transversal. 


\section{Análise por Microscopia Eletrônica de Varredura}

Em ambos os grupos (experimental e controle) incisivos superiores recém-extraídos foram adequadamente limpos e mantidos em recipientes individualizados contendo solução de Karnovsky modificada (glutaraldeído a 8\%, paraformaldeído a 12\% e cacodilato de sódio 0,2M; pH 7,2 - 7,4) para fixação, por um período mínimo de 5 dias. Decorrido esse período, os dentes foram lavados em solução tampão de cacodilato de sódio a 0,1M e, então, foram secos para serem submetidos à análise. Para este procedimento, os espécimes foram montados em "stubs" e, em seguida, receberam banho de ouro em metalizador Emitech K650 Spitter Coater (London, England), até a obtenção de uma espessura aproximada de $200 \mu \mathrm{m}$. Após metalização, os espécimes foram avaliados em Microscópio Eletrônico de Varredura DSM 940A (Zeiss, Oberkochen, Germany). Foram utilizados 5 incisivos superiores de cada grupo para analisar a estrutura da superfície externa do esmalte, empregando aumentos de 50, 500 e 1.500 vezes, tendo como referência a região incisal do dente. Para a avaliação da estrutura do esmalte e da dentina, em profundidade, foram utilizados também 5 incisivos superiores de cada grupo, previamente desgastados na sua superfície mesial até a exposição da dentina, os quais foram analisados com aumentos de 500 e 2.000 vezes, tendo como referência a junção amelo-dentinária.

Os parâmetros analisados foram: aspecto da superfície vestibular e contorno do esmalte, espessura e contorno dos prismas e possíveis defeitos estruturais do esmalte e características dos túbulos dentinários.

A sequência da metodologia empregada para análise por microscopia eletrônica de varredura encontra-se ilustrada no fluxograma 5. 

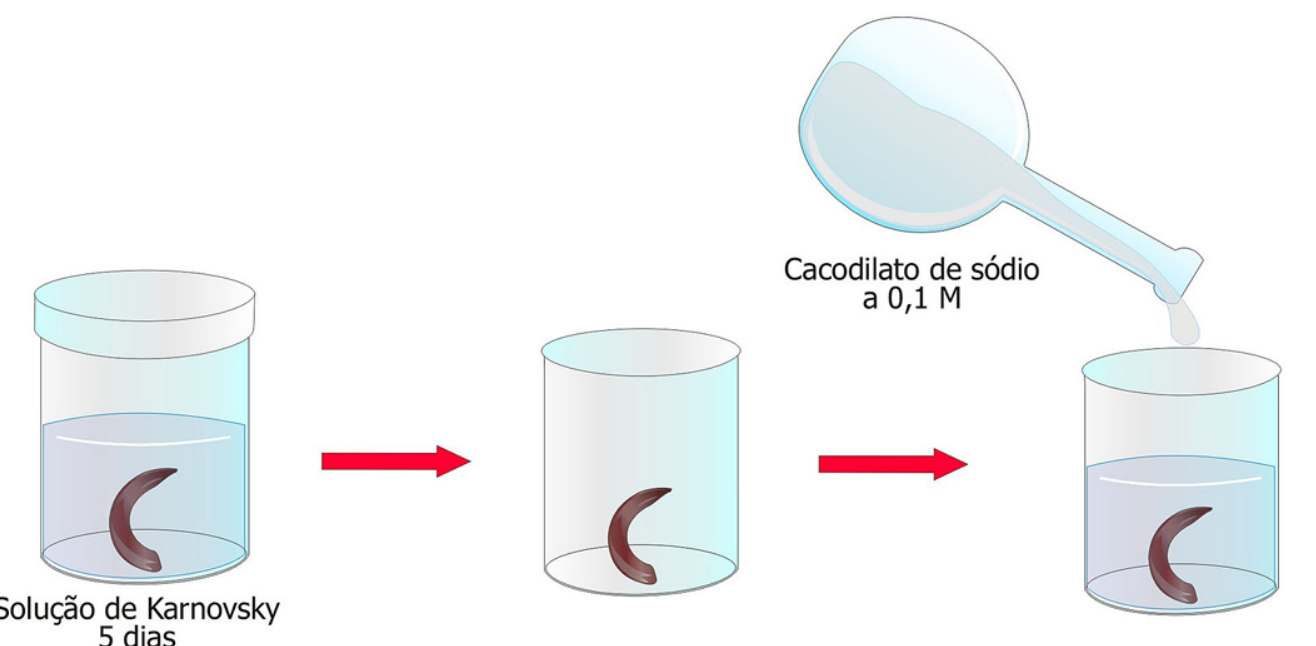
Solução de Karnovsky
5 dias

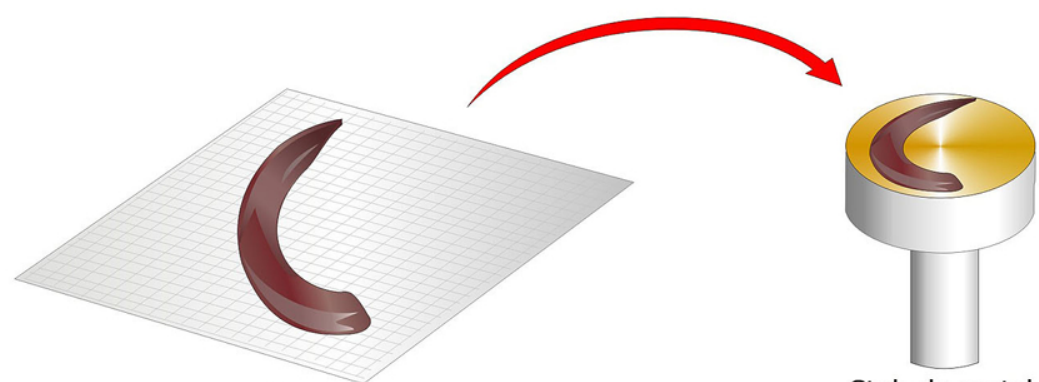

Secagem

Stub de metal
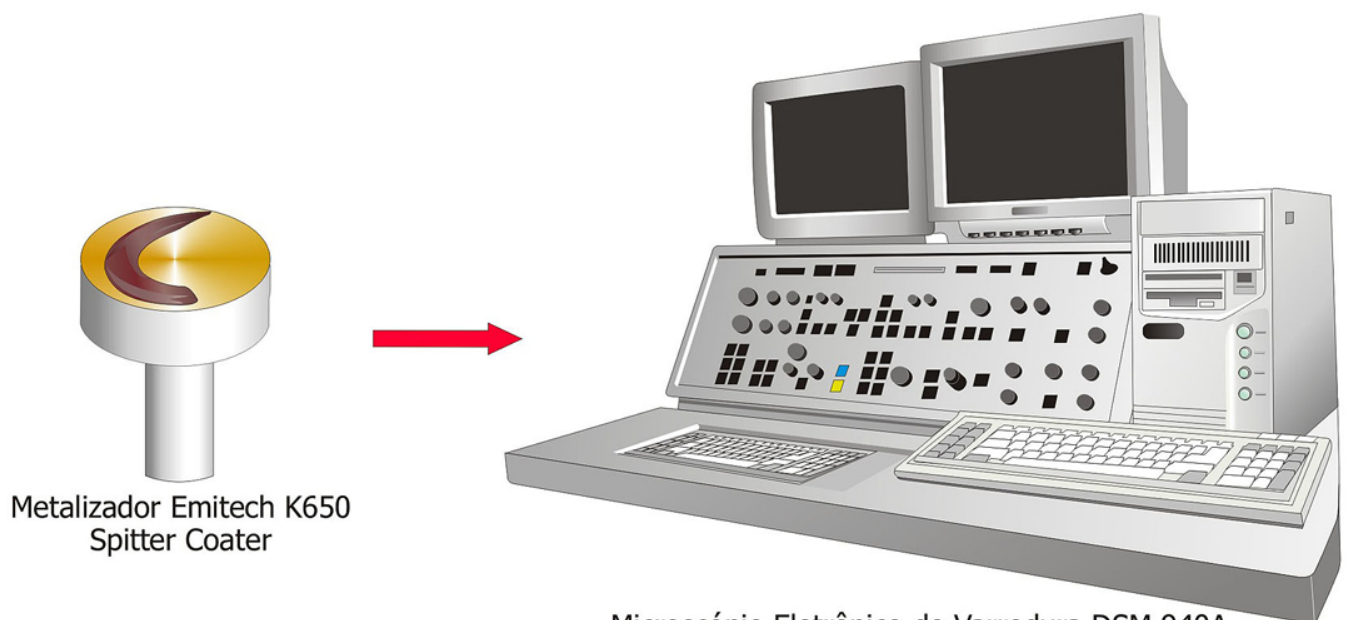

Microscópio Eletrônico de Varredura DSM 940A

Fluxograma 5. Metodologia empregada para a análise por microscopia eletrônica de varredura. 


\section{Análise por Microscopia de Luz Polarizada}

Para a análise em microscopia de polarização foram usados três incisivos superiores de cada grupo (experimental e controle), os quais foram armazenados em freezer à temperatura de $-20^{\circ} \mathrm{C}$ até o momento do preparo. Durante a preparação, os dentes foram desgastados e posteriormente polidos com lixas d'água de granulação 400, 600, 1200 e 4000 nas suas superfícies mesial e distal, até que se tornassem secções longitudinais de $100 \mu \mathrm{m}$ de espessura na sua porção média, previamente delimitada. A espessura foi mensurada com um paquímetro digital Vonder (Vonder Instrumentos de Medição, Brasil). Os dentes foram mantidos em solução de azida sódica a 0,02\%. Posteriormente, os dentes foram lavados em água destilada e submetidos ao preparo da lâmina em água, para, então, serem realizadas as análises qualitativas utilizando-se microscopia óptica de campo claro e microscopia óptica de polarização, em microscópio Axioskop 40 (Carl Zeiss, Alemanha). As amostras representativas de cada grupo foram fotografadas, em uma única sessão, sob condições padronizadas de iluminação e configurações usando uma câmera digital CMOS 1/2.5 (Moticam 2500, Motic, China), acoplada ao microscópio polarizador e lentes objetivas de 10, 20 e 40X.

Os parâmetros avaliados foram: espessura e mineralização do esmalte e deposição de ferro na superfície do esmalte.

A sequência da metodologia empregada para análise por microscopia de luz polarizada encontra-se ilustrada no fluxograma 6. 

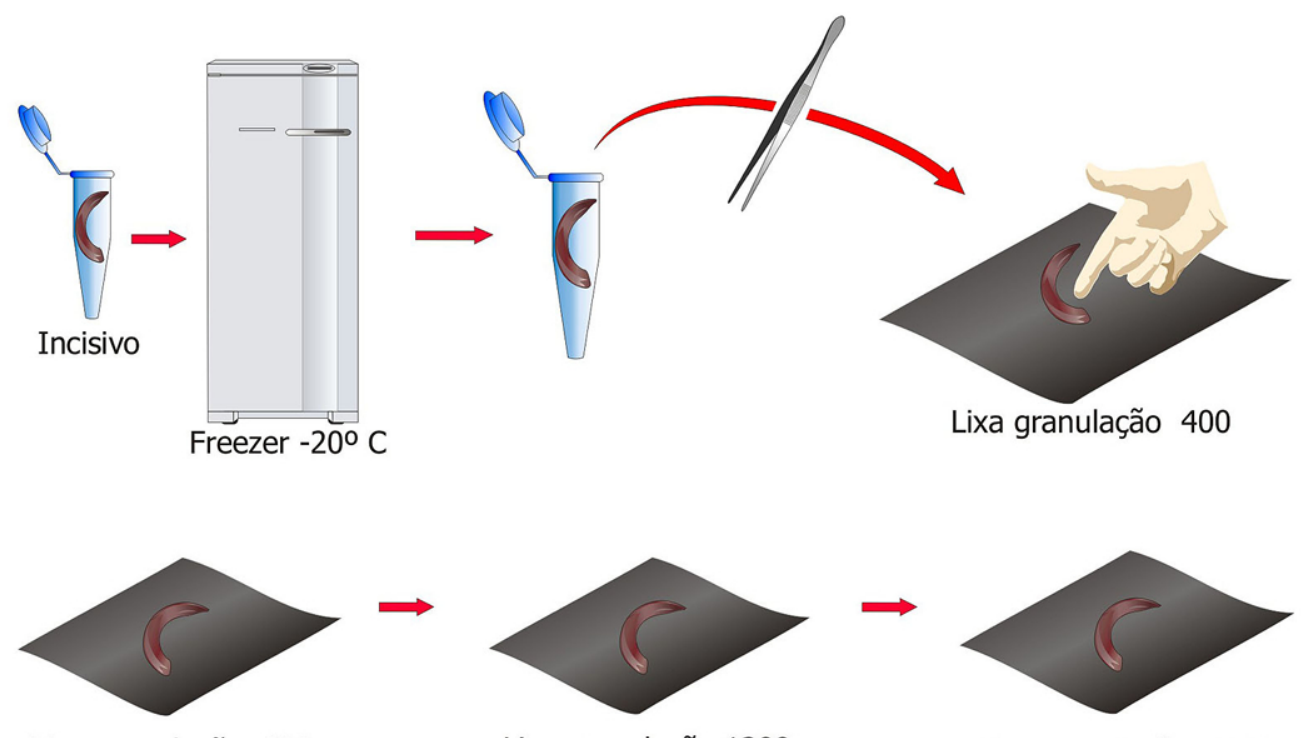

Lixa granulação 600

Lixa granulação 1200

Lixa granulação 4000

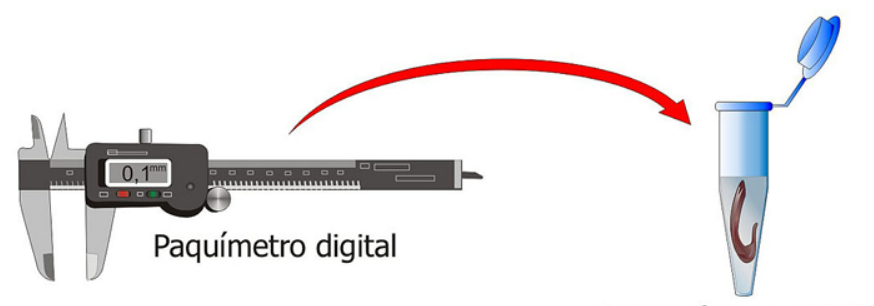

Azida sódica a $0,02 \%$
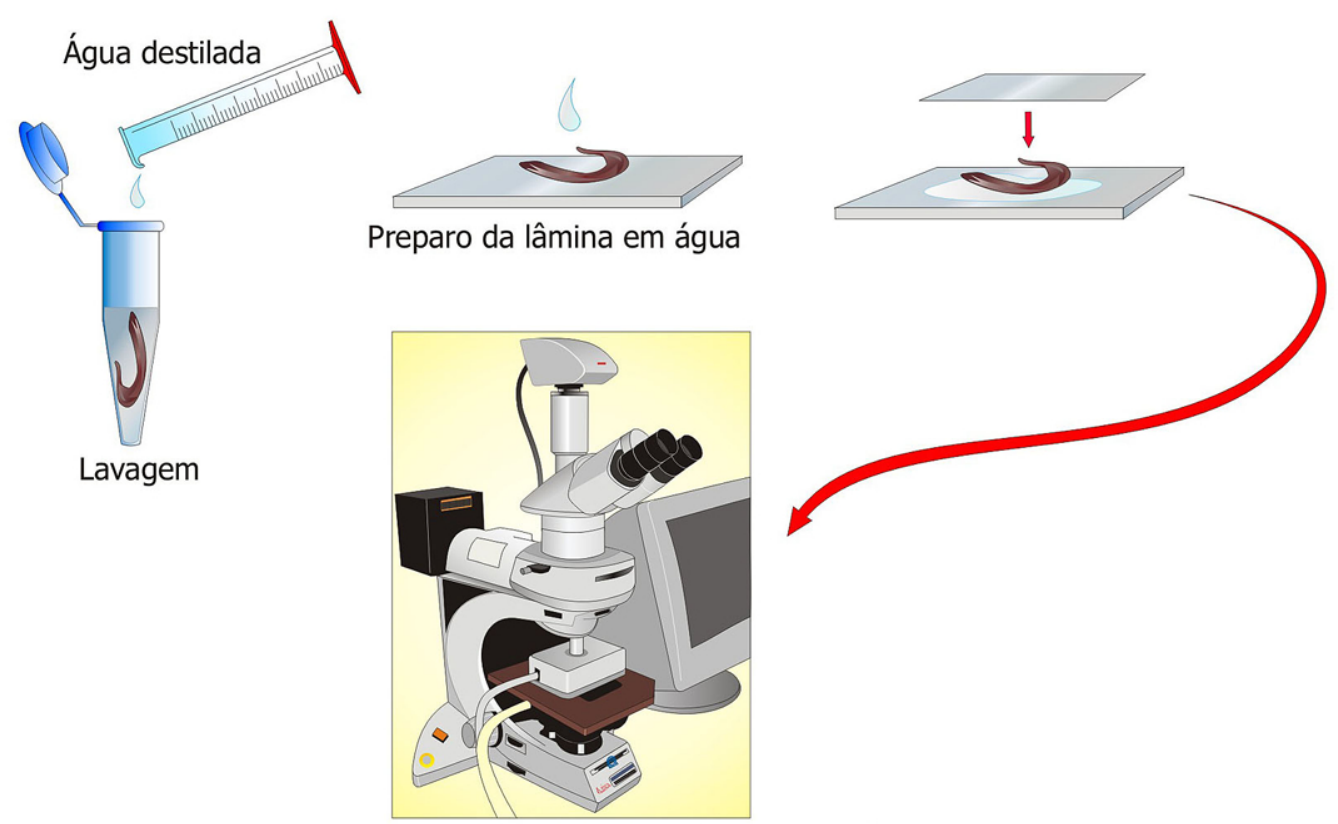

Microscópio Axioskop 40 / Câmera digital CMOS 1/2.5

Fluxograma 6. Metodologia empregada para a análise por microscopia de luz polarizada. 
Resultados 


\section{RESULTADOS}

A Figura 5 representa o monitoramento do peso corporal dos animais no período de 2 meses nos quais receberam os diferentes tratamentos. Com o decorrer desse período, observou-se aumento gradativo do peso corporal dos animais, desde a primeira até a oitava semana do experimento, demonstrando que os diferentes tratamentos realizados não interferiram no crescimento natural dos animais.

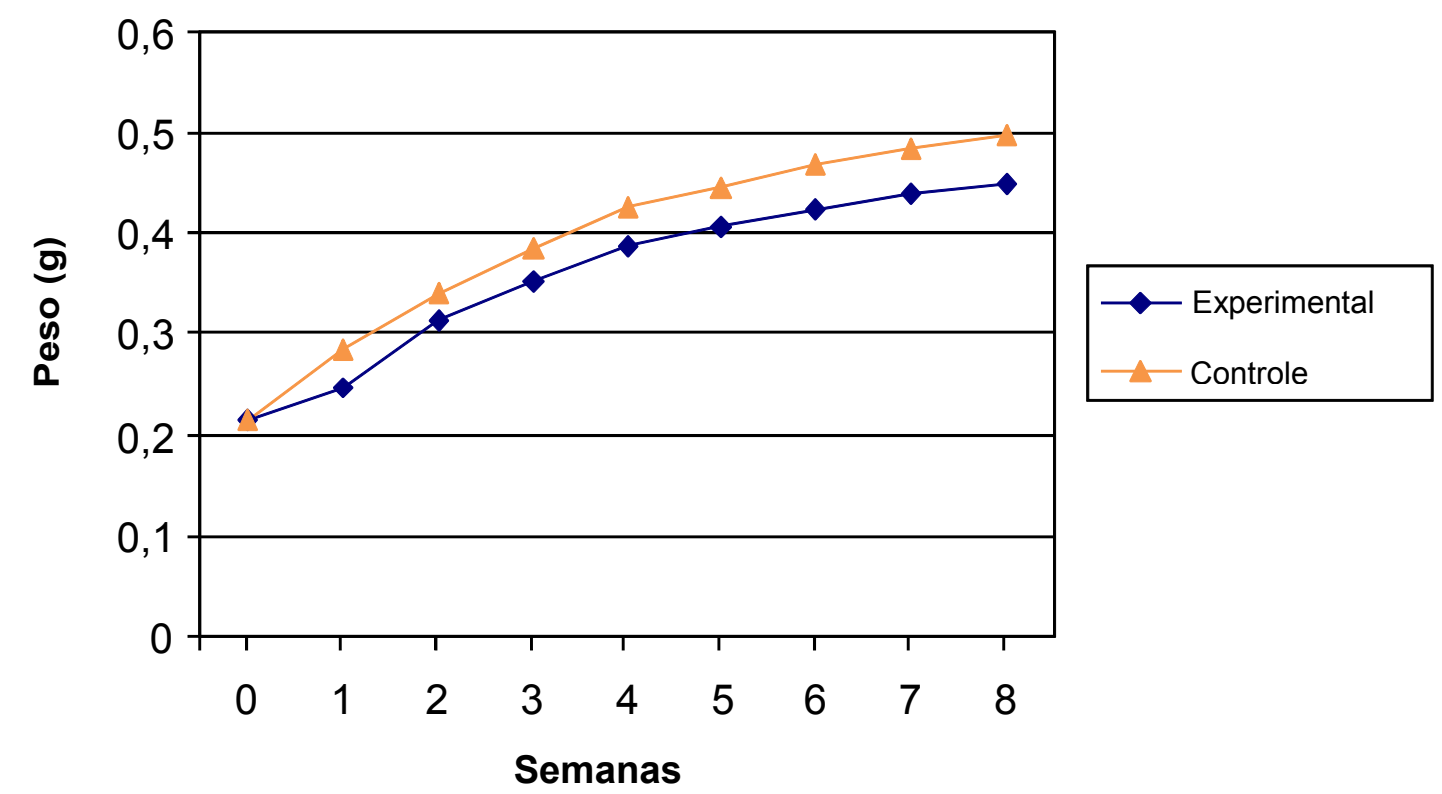

Figura 5. Média do peso corporal dos animais dos grupos experimental (administração de alendronato sódico) e controle (administração de água destilada), durante 8 semanas de tratamento.

\subsection{Análise da Densidade Mineral Óssea Radiográfica e por meio da Técnica de Absortometria Radiológica de Dupla Energia (DXA)}

As figuras 6 e 7 ilustram a comparação das distribuições de densidade mineral óssea (BMD) entre os grupos experimental e controle, obtidas pelo método da densitometria óptica radiográfica e pela técnica de absortometria radiológica de dupla energia (DXA), respectivamente. 


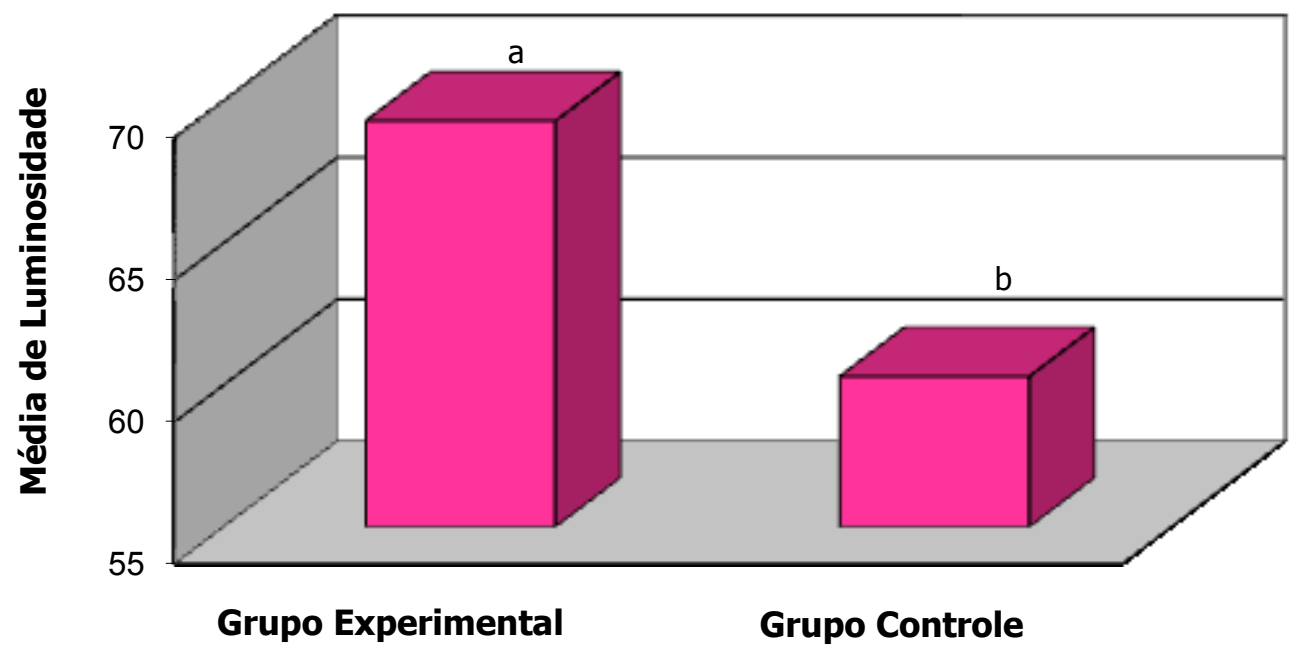

Figura 6. Comparação da densidade mineral óssea (valor médio da intensidade de luminosidade) entre os grupos experimental (administração de alendronato sódico) e controle (administração de água destilada), pelo método da densitometria óptica radiográfica. Letras distintas significam diferença estatisticamente significante.

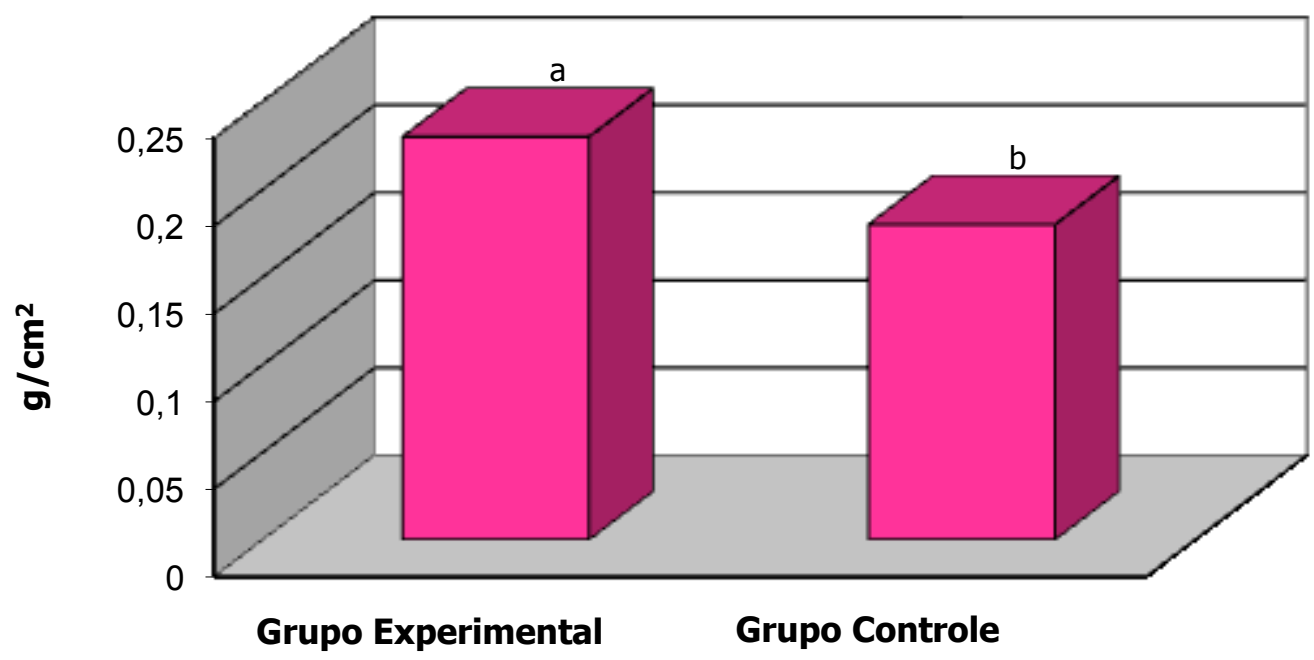

Figura 7. Comparação da densidade mineral óssea $\left(\mathrm{g} / \mathrm{cm}^{2}\right)$ entre os grupos experimental (administração de alendronato sódico) e controle (administração de água destilada), pelo método da absortometria radiológica de dupla energia (DXA). Letras distintas significam diferença estatisticamente significante.

Na tabela 1 estão apresentadas as comparações das distribuições dos valores de densidade mineral óssea (BMD) da metáfise proximal da tíbia, obtidas pelo método radiográfico (média de luminosidade) e pela técnica de absortometria radiológica de dupla energia (DXA) $\left(\mathrm{g} / \mathrm{cm}^{2}\right)$, nos grupos experimental e controle, após 8 semanas de experimento. 
Tabela 1. Comparação da densidade mineral óssea da metáfise proximal das tíbias, pelo método radiográfico (valor médio da intensidade de luminosidade) e pela técnica de absortometria radiológica de dupla energia (DXA) $\left(\mathrm{g} / \mathrm{cm}^{2}\right)$, entre os grupos experimental (administração de alendronato sódico) e controle (administração de água destilada)

\begin{tabular}{lccr}
\hline & $\begin{array}{c}\text { Grupo Experimental } \\
(\mathbf{n}=\mathbf{1 6})\end{array}$ & $\begin{array}{c}\text { Grupo Controle } \\
(\mathbf{n = 1 0 )}\end{array}$ & \\
\hline \hline & $\mathrm{M}(\mathrm{Q} 1-\mathrm{Q} 3)$ & $\mathrm{M}(\mathrm{Q} 1-\mathrm{Q} 3)$ & $P^{*}$ \\
Radiográfico & $66,8(64,1-72,6)$ & $60,5(57,9-62,8)$ & 0,0010 \\
DXA & $0,230(0,197-, 252)$ & $0,181(0,176-, 185)$ & 0,0001 \\
& & & \\
\hline $\begin{array}{l}\text { * valor de } p \text { para o teste de Kruskal-Wallis } \\
\text { M: mediana } \\
\text { Q1: primeiro quartil } \\
\text { Q3: terceiro quartil }\end{array}$ & & & \\
\end{tabular}

Os valores da densidade mineral óssea da metáfise proximal da tíbia apresentaram diferença significativa $(p<0,05)$ entre os grupos experimental e controle, pelos métodos da densitometria óptica radiográfica e absortometria radiológica de dupla energia (DXA). $O$ grupo experimental, o qual recebeu tratamento com alendronato sódico apresentou valores de densidade mineral óssea superiores em relação ao grupo controle, o qual recebeu apenas água destilada (veículo). Quando foi calculado o aumento, em porcentagem, da densidade mineral óssea entre os grupos experimental e controle, a partir das distribuições dos valores obtidos por ambos os métodos, a porcentagem de ganho pelo método radiográfico foi de $14,9 \%$ e a porcentagem de ganho pelo método de absortometria radiológica de dupla energia foi de $29,9 \%$. Esses resultados comprovaram que a metodologia de administração do alendronato sódico empregada no presente estudo foi adequada, uma vez que observouse seus efeitos em nível sistêmico.

\subsection{Análise Química Qualitativa da Incorporação do Alendronato Sódico nas Estruturas Dentárias por Espectrometria na Região do Infravermelho}

As figuras 8, 9 e 10 representam os espectros na região do infravermelho, em pastilhas de $\mathrm{KBr}$, da amostra obtida do alendronato sódico quimicamente puro e das amostras obtidas dos dentes (esmalte e dentina) de ambos os grupos (controle e experimental). 


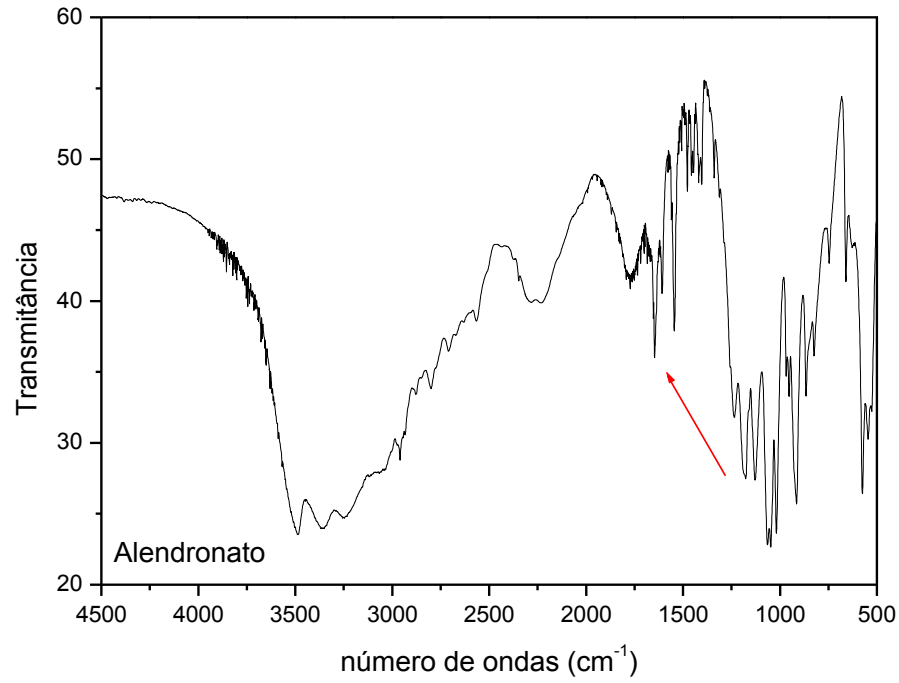

Figura 8. Espectro na região do infravermelho, em pastilha de $\mathrm{KBr}$, do alendronato sódico quimicamente puro.

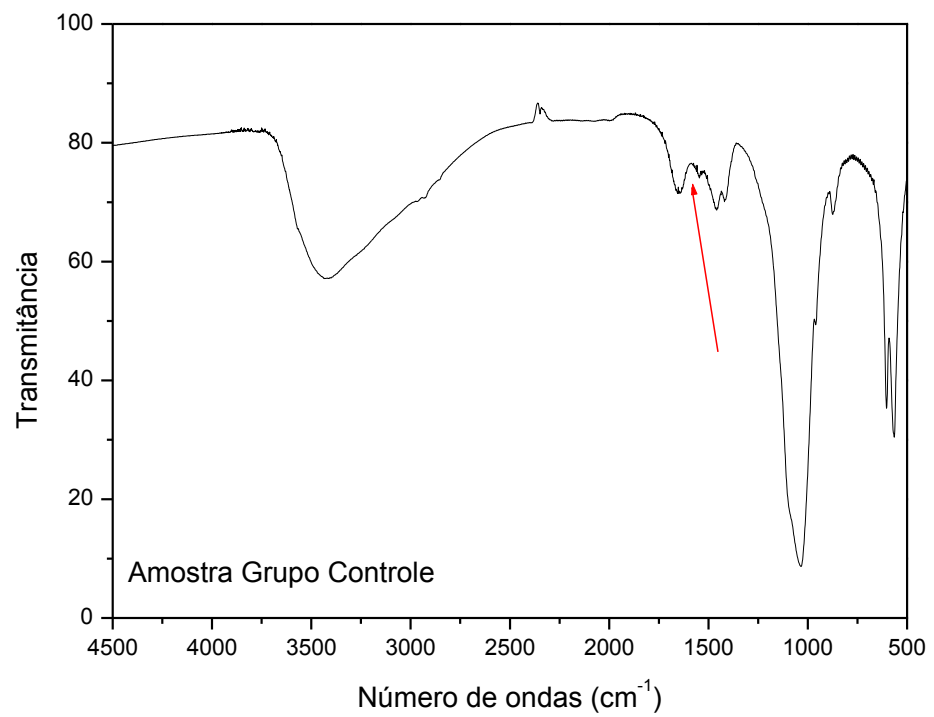

Figura 9. Espectro na região do infravermelho, em pastilha de $\mathrm{KBr}$, da amostra obtida do dente do grupo controle. 


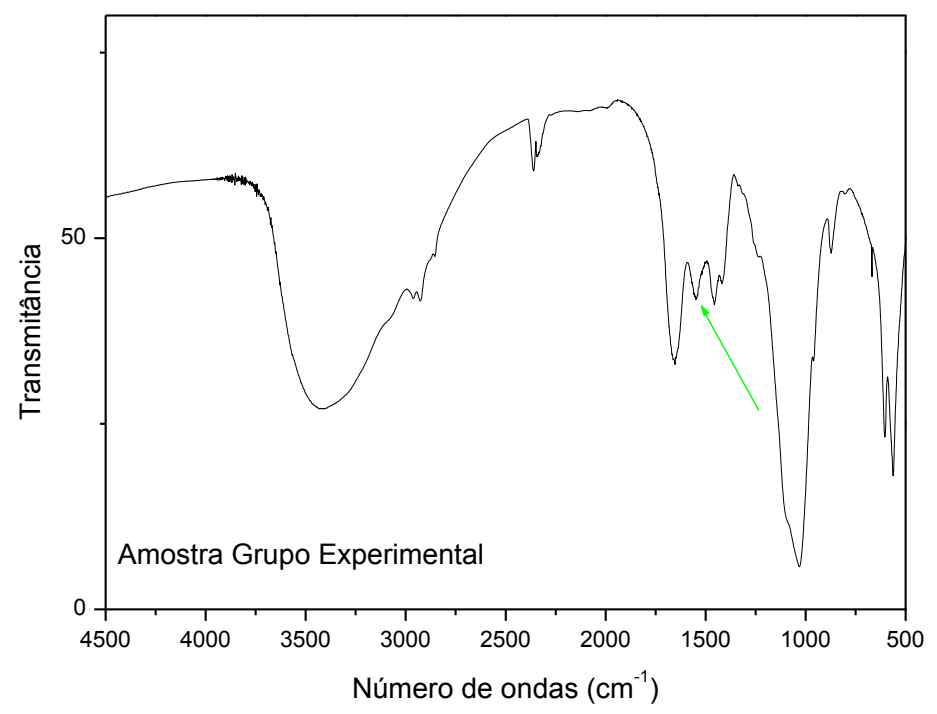

Figura 10. Espectro na região do infravermelho, em pastilha de $\mathrm{KBr}$, da amostra obtida do dente do grupo experimental.

Comparando-se os espectros obtidos a partir das amostras dos dentes de ambos os grupos com o espectro do alendronato sódico puro, foi possível inferir a presença de alendronato na amostra do grupo experimental. Este fato se deve à presença de uma banda na região de 2.000 a $1.500 \mathrm{~cm}^{-1}$, que é característica de ligações do tipo $\mathrm{CH}$, presentes na estrutura química do alendronato sódico.

\subsection{Análise Química Quantitativa da Incorporação do Alendronato Sódico nas Estruturas Dentárias por Espectroscopia de Fluorescência}

O espectro de emissão, $\lambda_{\mathrm{ex}}=266 \mathrm{~nm}$, do derivado alendronato/FMOC está apresentado na Figura 11A, onde também estão indicados os volumes de solução estoque de alendronato $(0,0215 \mathrm{~g}$ em $250 \mathrm{~mL}$ de água) utilizados para preparar cada solução para construção da curva de calibração (Figura 11B).

A curva de calibração do derivado de alendronato/FMOC foi construída utilizando-se os valores máximos de intensidade de fluorescência em $\lambda_{\mathrm{em}}=315 \mathrm{~nm}$. Observou-se que, com o aumento da concentração de alendronato na solução, a intensidade de fluorescência também aumentou (Figura 11B). 

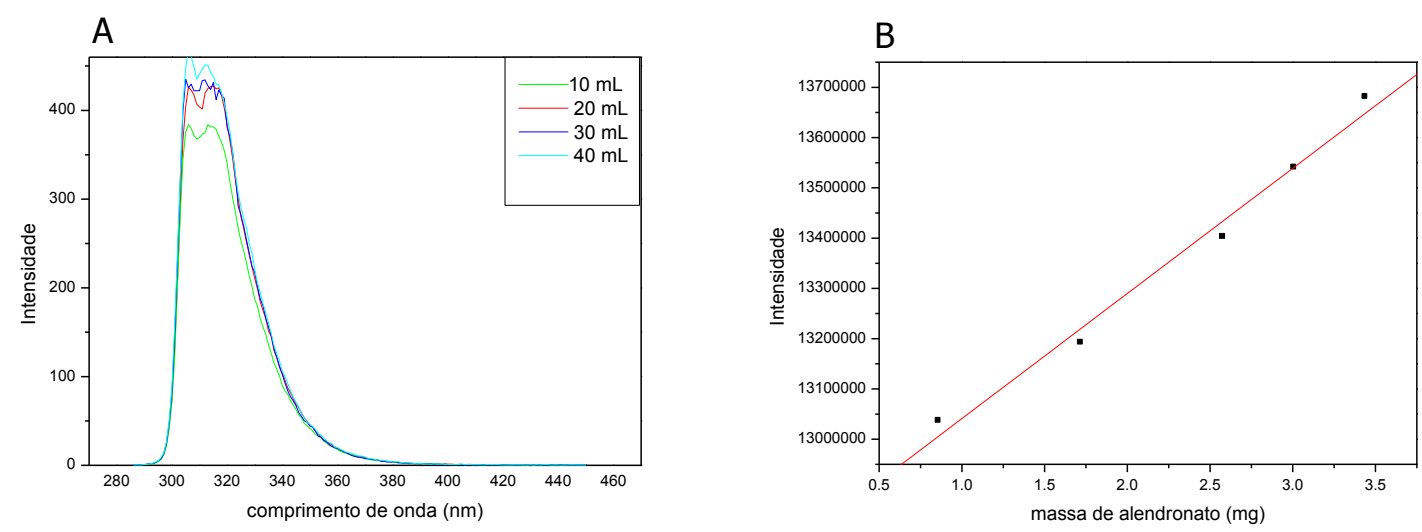

Figura 11. (A) Espectros de emissão $\left(\lambda_{\text {ex }}=266 \mathrm{~nm}\right)$ das soluções do derivado de alendronato/FMOC a diferentes concentrações, para construção da curva de calibração (B).

Os espectros de emissão das soluções obtidas das amostras dos dentes do grupo controle e do grupo experimental estão apresentados na Figura 12. Observou-se que 0 espectro de emissão do derivado de alendronato/FMOC em solução de citrato de sódio e borato de sódio, quando excitado em 266 nm, apresentou banda de emissão com máximo em $315 \mathrm{~nm}$. Isto não foi observado na leitura da amostra do grupo controle, já que teoricamente não há presença de alendronato. Esses resultados evidenciaram que o alendronato foi incorporado à estrutura dental mineralizada, como observado na curva representativa do grupo experimental.

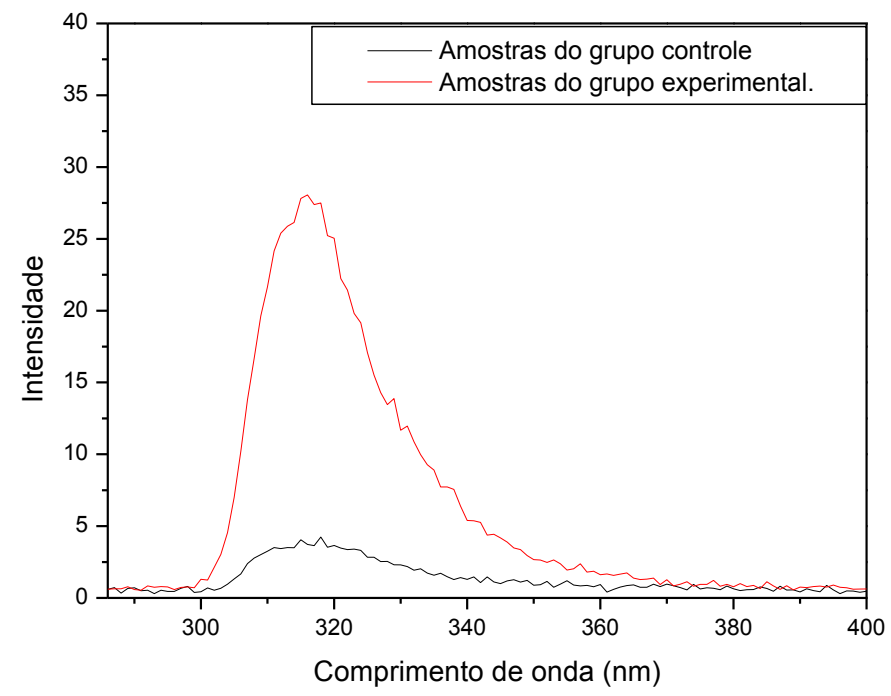

Figura 12. Espectros de emissão $\left(\lambda_{\mathrm{ex}}=266 \mathrm{~nm}\right)$ das soluções obtidas das amostras do grupo controle e do grupo experimental. 
A partir da curva de calibração foi possível determinar a quantidade de alendronato incorporada nas estruturas dentais mineralizadas. A porcentagem de alendronato incorporado em cada dente foi de 0,0018\%.

\subsection{Avaliação do Efeito da Incorporação do Alendronato Sódico nas Estruturas Dentárias Mineralizadas}

\section{Análise da Microdureza Transversal}

Na tabela 2 estão apresentados os valores e as comparações da microdureza

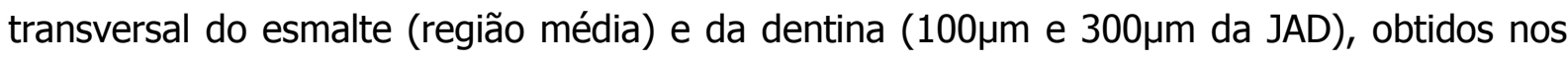
dentes de ratos dos grupos experimental e controle, após 8 semanas de experimento.

Tabela 2. Comparação da microdureza transversal (Knoop) do esmalte e da dentina nos grupos experimental (administração de alendronato sódico) e controle (administração de água destilada)

\begin{tabular}{|c|c|c|c|}
\hline & $\begin{array}{l}\text { Grupo Experimental } \\
(n=20)\end{array}$ & $\begin{array}{c}\text { Grupo Controle } \\
(n=12)\end{array}$ & \\
\hline & $\mathrm{M}(\mathrm{Q} 1-\mathrm{Q} 2)$ & $M(Q 1-Q 2)$ & $P^{*}$ \\
\hline & $220,7(201,6-255,1)$ & $242(225-261,6)$ & 0,2273 \\
\hline \multicolumn{4}{|l|}{ Esmalte } \\
\hline Dentina $(100 \mu \mathrm{m})$ & $62,4(55,0-69,0)$ & $51,9(47,7-76.6)$ & 0,6685 \\
\hline Dentina $(300 \mu \mathrm{m})$ & $51,6(43,1-58,1)$ & $51,0(37,0-55,8)$ & 0,5858 \\
\hline
\end{tabular}

A figura 13 ilustra a comparação das distribuições dos valores da microdureza transversal entre os grupos experimental e controle. 


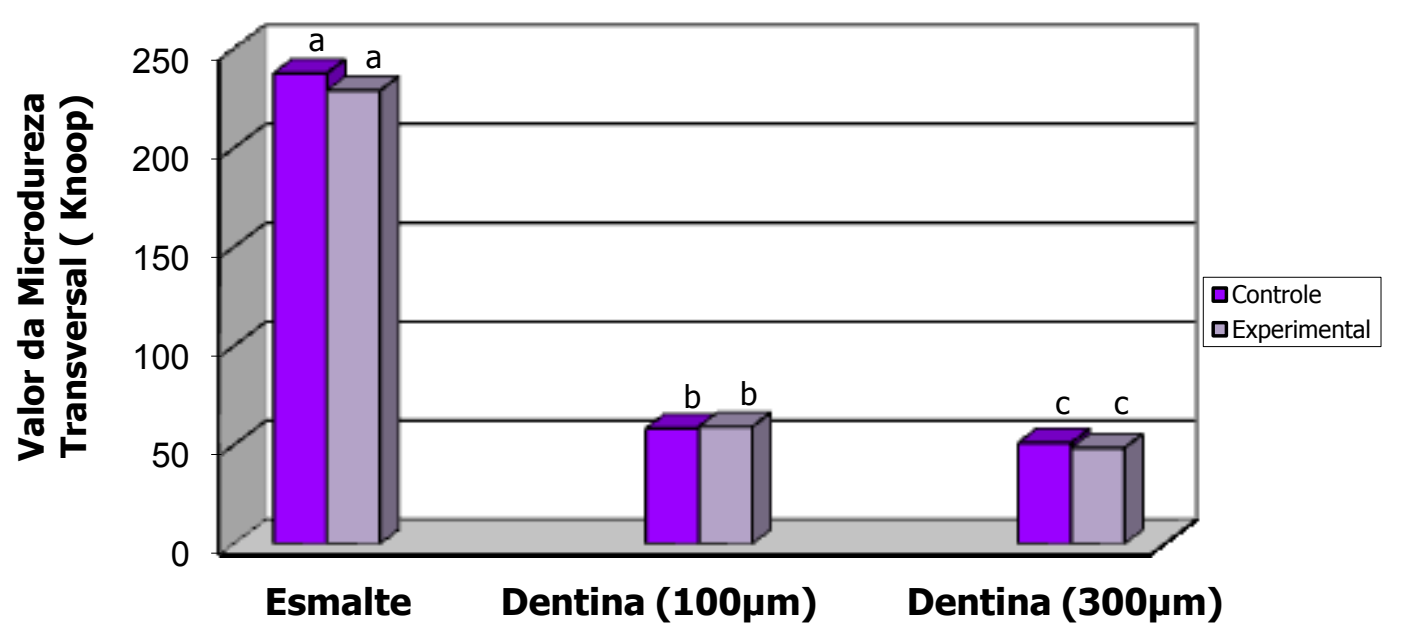

Figura 13. Comparação da microdureza transversal do esmalte e da dentina entre os grupos experimental (administração de alendronato sódico) e controle (administração de água destilada). Letras iguais significam que não há diferença estatisticamente significante.

Os resultados da microdureza transversal do esmalte (região média) e da dentina nos dois níveis de profundidade avaliados (a $100 \mu \mathrm{m}$ e a $300 \mu \mathrm{m}$ da JAD) não revelaram diferença estatisticamente significante entre os grupos experimental e controle $(p>0,05)$, evidenciando que a administração de alendronato sódico não alterou a microdureza transversal do esmalte e da dentina de dentes de ratos, em comparação ao grupo controle.

\section{Análise por Microscopia Eletrônica de Varredura}

As eletromicrografias da superfície vestibular e do corte transversal (esmalte e dentina) dos incisivos de ratos dos grupos experimental e controle estão apresentadas nas figuras 14 e 15 , respectivamente.

A superfície vestibular do esmalte dos incisivos, em ambos os grupos (controle e experimental) apresentou-se homogênea, sem alteração na porosidade e com contorno regular.

Quando o esmalte e a dentina foram avaliados transversalmente, também não foram encontradas diferenças entre os dentes de ambos os grupos e as características observadas foram condizentes com aspectos de normalidade. O esmalte dos incisivos apresentou espessura, contorno dos prismas e mineralização regulares, com ausência de alterações.

Os túbulos dentinários em ambos os grupos estavam abertos, sem oclusão da entrada dos mesmos. 


\section{Análise por Microscopia de Luz Polarizada}

A comparação das imagens obtidas dos grupos experimental e controle, as quais estão apresentadas nas figuras 14 e 15, respectivamente, evidenciou que a espessura do esmalte não estava alterada e nenhum sinal de aumento na retenção de componente orgânico no esmalte desenvolvido na presença de alendronato sódico foi observado nos cortes examinados por microscopia de luz polarizada. Adicionalmente, não houve diferença na morfologia dos prismas de esmalte entre as amostras de ambos os grupos.

Na análise morfológica foi possível visualizar as três camadas histológicas do esmalte (superficial, média e profunda), com a camada média tendo o maior conteúdo mineral, seguida pelas camadas interna e externa, não havendo diferenças entre os grupos.

Não foram observadas alterações na pigmentação de ferro nas áreas superficiais do esmalte após a administração do alendronato sódico, em comparação ao grupo controle. 
Figura 14 - GRUPo EXPERIMENTAL - AdMinistração De ALENDRonato Sódico

\section{IMAgens Obtidas por Microscopia Eletrônica de VARRedura}

A - Visão panorâmica da superfície vestibular do incisivo (50X), evidenciando contorno regular.

B - Maior aumento da Figura A (1.500X), evidenciando ausência de defeitos estruturais.

C - Visão panorâmica do esmalte e da dentina em profundidade (500X).

D - Maior aumento do esmalte (2.000X) da Figura C, evidenciando ausência de alterações no contorno dos prismas e de defeitos estruturais do esmalte.

E - Maior aumento da dentina (2.000X) da Figura C, evidenciando a presença de túbulos dentinários, sem oclusão da entrada dos mesmos.

\section{Imagens Obtidas POR Microscopia Óptica de Campo ClaRo e Microscopia}

\section{ÓPTICA DE LUZ POLARIZADA}

F - Aspecto do esmalte e da dentina em microscopia de campo claro (20X), evidenciando ausência de alterações na espessura do esmalte e na pigmentação de ferro nas áreas superficiais.

G - Aspecto do esmalte e da dentina em microscopia de polarização (20X), evidenciando as três camadas histológicas do esmalte (superficial, média e profunda).

H - Aspecto do esmalte em maior aumento em microscopia de campo claro (50X), evidenciando ausência de alterações na espessura do esmalte e de aumento na retenção de componente orgânico. 

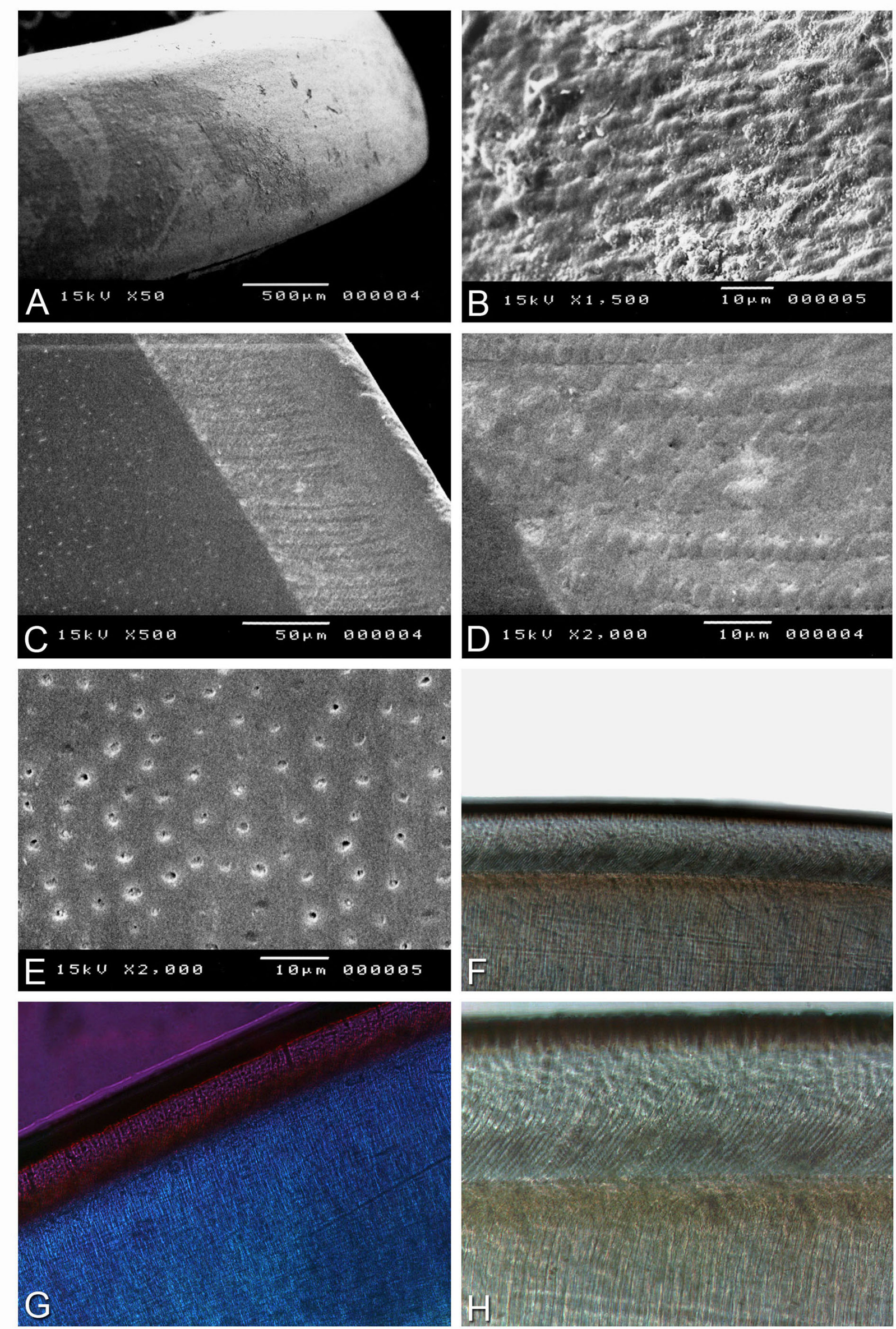


\section{Figura 15 - Grupo Controle - Administração De Água DestiladA}

\section{ImAgens ObTidas POR Microscopia Eletrônica de VARRedura}

A - Contorno regular da superfície vestibular do incisivo, em aumento de 50X.

B - Maior aumento da Figura A (1.500X), onde observa-se ausência de defeitos estruturais.

C - Visão panorâmica do esmalte e da dentina em profundidade (500X).

D - Visão panorâmica do esmalte e da dentina em profundidade (500X).

E - Maior aumento do esmalte (2.000X) da Figura C. Não foram observadas alterações no contorno dos prismas e de defeitos estruturais do esmalte.

\section{Imagens Obtidas por Microscopia Óptica de CAMpo Claro e Microscopia}

\section{ÓPTICA DE LUZ POLARIZADA}

F - Aspecto do esmalte e da dentina em microscopia de campo claro (20X). Ausência de alterações na espessura do esmalte e na pigmentação de ferro nas áreas superficiais.

G - Aspecto do esmalte e da dentina em microscopia de polarização (20X), evidenciando as três camadas histológicas do esmalte (superficial, média e profunda).

H - Aspecto do esmalte em maior aumento em microscopia de campo claro (50X), onde observa-se ausência de alterações na espessura do esmalte e de aumento na retenção de componente orgânico. 

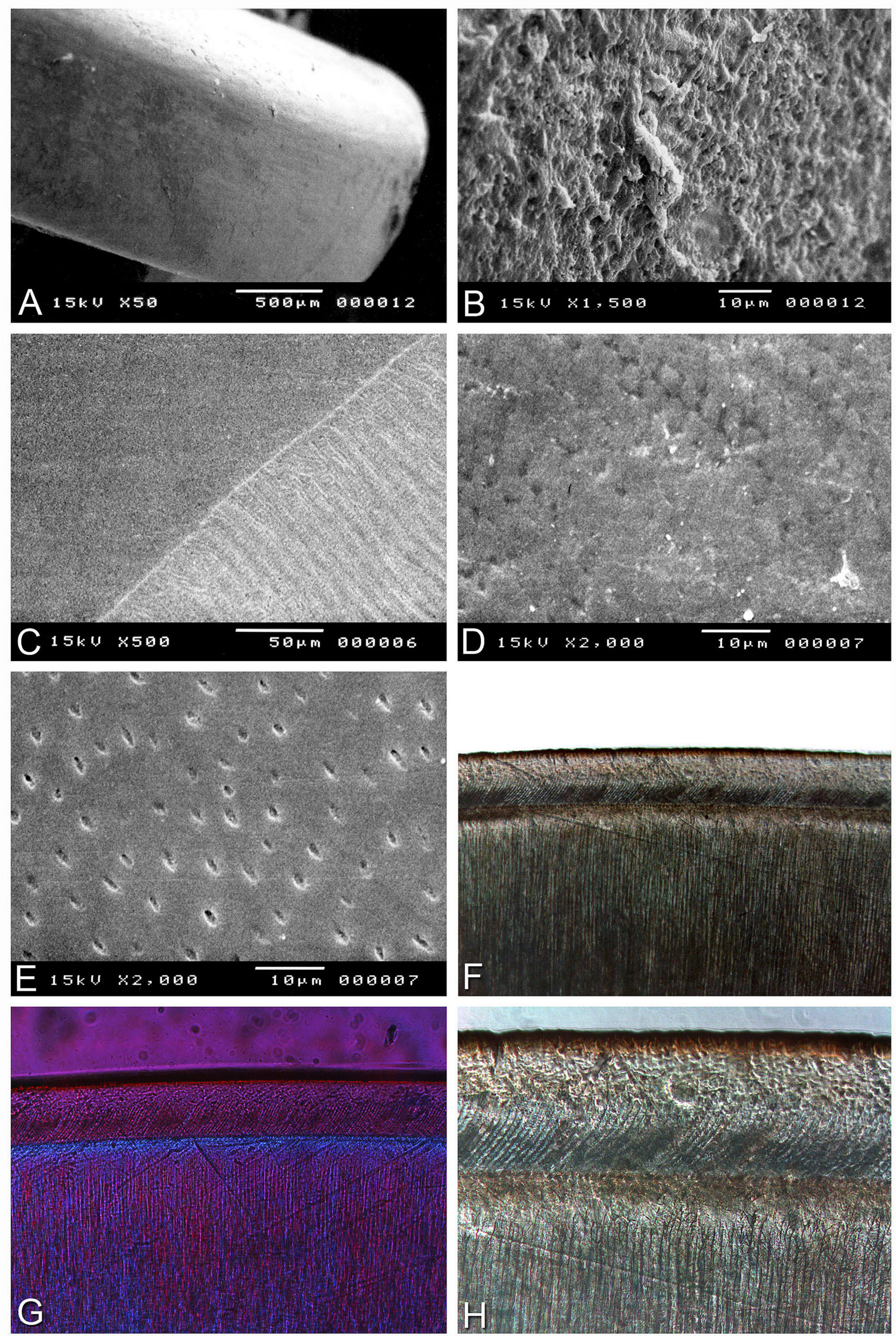
Discussão 


\section{Discussão}

A odontogênese inicia-se com uma série de interações complexas entre as células e entre estas e a matriz, que resultam na diferenciação de odontoblastos e ameloblastos, os quais formam dentina e esmalte, respectivamente (Thesleff et al., 1995). Assim que a amelogênese se inicia, células do epitélio interno do órgão do esmalte passam por um processo de diferenciação relativamente lento, antes de se tornarem ameloblastos secretórios. Enquanto isso, células ectomesenquimais periféricas da papila dentária diferenciam-se em odontoblastos e iniciam a secreção de dentina (Arana-Chavez e Massa, 2004). Uma vez a dentina do manto esteja formada, os ameloblastos completam sua diferenciação e secretam grandes quantidades de várias proteínas do esmalte. As proteínas secretadas se organizam para formar uma complexa matriz de esmalte extracelular, tornando-se um meio ambiente propício à recepção mineral, que controla o início e a taxa de crescimento de cristalitos minerais (Nanci et al., 1998).

A amelogênese pode ser dividida em, no mínimo, três fases: secreção, quando a maior parte das proteínas do esmalte é secretada; transição, quando os ameloblastos perdem a maioria de suas organelas secretoras, reduzem e perdem seus processos de Tomes, e ocorre uma invasão capilar em direção ao órgão do esmalte; e maturação, estágio no qual o esmalte perde água e matéria orgânica, que é substituída pelo crescimento de cristais, tornando-se o tecido mais altamente mineralizado do organismo (Robinson et al., 1979).

É conhecido que uma grande variedade de condições e drogas podem causar distúrbios na formação e mineralização do esmalte humano (Small e Murray, 1978), porém o diagnóstico clínico das alterações patológicas ocorridas raramente permite ao profissional identificar o fator etiológico (Fejerskov et al., 1990).

Os defeitos de desenvolvimento do esmalte têm sido classificados em hipoplasia e hipomineralização (Suckling, 1989). A hipoplasia de esmalte é causada por distúrbios de diferenciação celular e, subsequentemente, da síntese e secreção de substâncias orgânicas. O distúrbio de mineralização do esmalte parece ser um processo mais complicado, que pode ser mediado tanto por funções prejudicadas das células do órgão do esmalte quanto por desordem dos eventos extracelulares que ocorrem durante o estágio de maturação (Sato et al., 1996).

Com relação aos possíveis eventos extracelulares responsáveis pelo desenvolvimento de malformações do esmalte, grande atenção tem sido dada ao atraso da secreção da matriz, alteração do processo pós-secretório das proteínas, inibição da nucleação e crescimento dos cristais ou atraso da remoção da matriz e da mineralização secundária (Sato et al., 1996). 
Vários estudos demonstraram os efeitos do etidronato (HEBP), bisfosfonato que não contém nitrogênio, na fibrilogênese de colágeno na dentina (Larsson, 1974; Ogawa et al., 1989), na síntese de matriz dentinária (Beertsen et al., 1985) e na mineralização da dentina (Takano et al., 1998; Sakai et al., 1999). Adicionalmente, pesquisas têm demonstrado os efeitos dessa droga na mineralização do esmalte (Weile et al., 1990), na morfologia do ameloblasto (Fejerskov et al., 1990; Josephsen et al., 1990) e nas funções dessas células, incluindo efeitos na síntese e secreção de proteínas (Fuangtharnthip et al., 2000; Yamada et al., 2000).

No entanto, o presente estudo objetivou avaliar in vivo os efeitos do uso sistêmico do alendronato sódico, na densidade mineral óssea e nas estruturas dentárias mineralizadas de incisivos murinos, de acordo com diferentes parâmetros de avaliação, por ser esse um medicamento pertencente ao grupo dos bisfosfonatos aminados, os mais amplamente prescritos atualmente, do ponto de vista clínico, em pacientes com desordens ósseas (Orbak et al., 2006; Inoue et al., 2008; Kawate et al., 2010).

De acordo com os resultados obtidos, o desenvolvimento dos tecidos dentários mineralizados analisados não foi alterado nos incisivos de ratos como consequência da exposição ao alendronato sódico na concentração de $1 \mathrm{mg} / \mathrm{Kg}$, administrado via gavagem, duas vezes por semana, durante um período de 60 dias, dose essa que simula a dosagem prescrita clinicamente para pacientes com desordens ósseas (informação presente na bula do medicamento, considerando $70 \mathrm{Kg}$ o peso médio dos adultos). Uma evidência para esta informação é fundamentada em um parâmetro físico usualmente empregado para avaliar a qualidade do esmalte e da dentina: os valores de microdureza (Gerlach et al., 2002). Os valores obtidos indicaram que a porção média da camada de esmalte e a dentina a 100 $\mu \mathrm{m}$ e a $300 \mu m$ da junção amelo-dentinária não tiveram sua dureza alterada em função do tratamento com o alendronato.

Evidências adicionais foram obtidas a partir das análises em microscopia eletrônica de varredura e microscopia de luz polarizada empregadas no presente estudo, as quais nos permitiram avaliar aspectos morfológicos. Não foi possível observar diferenças significativas entre os incisivos do grupo controle (expostos à água destilada apenas) e do grupo experiental (expostos ao alendronato sódico), segundo os parâmetros utilizados. Em microscopia eletrônica de varredura, a superfície vestibular do esmalte apresentou-se homogênea, sem alteração na porosidade e com contorno regular. Quando o esmalte e a dentina foram avaliados transversalmente, em microscopia eletrônica de varredura, também não foram encontradas diferenças entre os dentes de ambos os grupos e as características observadas foram condizentes com aspectos de normalidade. Em microscopia de luz polarizada, as imagens dos dois grupos (experimental e controle) evidenciaram ausência de alterações na espessura e morfologia do esmalte. 
Segundo Møinichen et al. (1996) e Ozbek et al. (2009), a estrutura do esmalte normal de incisivos murinos, em microscopia eletrônica de varredura, pode ser dividida em duas camadas principais: esmalte interno e esmalte externo. No esmalte interno, os prismas apresentam uma configuração característica, de forma que se dispõem arranjados em linhas de camada única, as quais são orientadas transversalmente em relação ao longo eixo do dente. Na parte externa do esmalte, todos os prismas tornam-se paralelos uns aos outros e correm em direção incisal. No corte transversal, a região interprismática exibe um padrão característico de "favo de mel". Na região entre a parte interna e a parte externa do esmalte, onde ocorre intersecção de prismas, as linhas de camada única de prismas englobam prismas pertencentes a diferentes lamelas. No presente estudo, as características do esmalte e da dentina de incisivos de ratos por meio de microscópio eletrônico de varredura também foram normais, concordantes com esses autores.

No estudo em microscopia de luz polarizada, as imagens obtidas no presente estudo foram compatíveis com a descrição de Saiani et al. (2009), ou seja, que há no esmalte do incisivo de rato duas camadas (uma superficial e outra adjacente ao limite amelo-dentinário) com a maior birrefringência positiva e uma camada média com a menor birrefringência positiva.

No entanto, os resultados do presente estudo são discordantes dos trabalhos que demonstraram que a administração de etidronato afeta a mineralização tanto da dentina quanto do esmalte (Simmelink, 1987; Ohya et al., 1989; Fejerskov et al., 1990; Weile et al., 1990; 1993; Fouda et al., 1991; Takano et al., 1998).

A administração de injeção única de etidronato em ratos induziu uma banda hipomineralizada na camada de esmalte (Ogawa et al., 1989; Josephsen et al., 1990; Fouda et al., 1989; 1992). Segundo Fouda et al. (1991), o exame microrradiográfico de molares de ratos revelou uma faixa de hipomineralização na matriz do esmalte, correspondente à superfície externa em desenvolvimento, no momento da injeção do etidronato. No entanto, na prática clínica o paciente é submetido a doses diárias de alendronato sódico (aminobisfosfonato) por longos períodos, como efetuado no presente estudo, e não de etidronato, em dose única.

Adicionalmente, foi demonstrado que o tratamento com alguns BFs não aminados, após administração de doses únicas ou múltiplas, interferiu na amelogênese, causando distúrbios nos ameloblastos e, consequentemente, no desenvolvimento do esmalte, incluindo hipoplasias e formação de cistos subameloblásticos (Simmelink, 1987; Fouda et al., 1989; 1991; 1992; Fejerskov et al., 1990). Segundo Fouda et al. (1989), os BFs que não contêm nitrogênio causam desorganização celular e fragmentação do processo de Tomes dos 
ameloblastos, o que poderia ser um dos fatores responsáveis pelo desprendimento destas células da superfície do esmalte e pela consequente formação das cavidades semelhantes a cistos. Os cistos ocorreram preferencialmente abaixo dos ameloblastos que estavam ao final do estágio de secreção (Fouda et al., 1989; 1991). Sabe-se que os processos de Tomes dos ameloblastos são reduzidos após a formação da matriz e é possível que essas células, devido a esta alteração morfológica, sejam mais facilmente destacadas da superfície de esmalte neste estágio do que em estágios anteriores (Fouda et al., 1991).

Fejerskov et al. (1990) avaliaram os efeitos do etidronato nos ameloblastos secretórios e as mudanças na zona de secreção interna do esmalte em incisivos de crescimento contínuo de ratos. Os animais foram mortos em intervalos regulares para obter informação sobre as mudanças morfológicas que ocorrem nas células e no esmalte em formação após a exposição à droga. Em todos os animais mortos 9 dias após uma única injeção de etidronato, os microrradiogramas revelaram uma área distinta de esmalte hipomineralizado percorrendo desde a junção amelo-dentinária até a superfície de esmalte, correspondente ao local de mineralização no período da injeção. O conteúdo mineral do esmalte remanescente bem como a sua espessura estava aparentemente normal, e o padrão dos prismas não foi alterado. Quando se comparou as características microscópicas dos ameloblastos secretórios em diferentes intervalos de tempo após a administração da droga, certas mudanças foram observadas. Decorridas 20 horas do momento da injeção, houve alterações profundas na interface entre os ameloblastos e a frente de mineralização e a parte intermediária dos processos de Tomes encontravam-se muito menos pronunciadas, quando comparadas aos controles.

De fato, os ameloblastos no estágio de maturação são essenciais para proporcionar a mineralização do esmalte, provavelmente controlando o influxo de minerais ou criando condições físicas para a precipitação de hidroxiapatita de uma maneira bastante controlada (Porto et al., 2009).

Yamada et al. (2000) propuseram elucidar a patogênese da hipoplasia de esmalte induzida por etidronato e, especialmente, determinar que processo inibitório da síntese e secreção de proteína está envolvido. Com base nos resultados obtidos, os autores sugeriram que a hipoplasia de esmalte nos ratos tratados com a droga não foram relacionadas a um distúrbio na síntese de amelogenina, mas a um distúrbio em um processo posterior, presumivelmente de secreção das proteínas do esmalte.

Segundo Fouda et al. (1989), as lesões hipoplásicas no esmalte aparecem como resultado do impedimento da formação de esmalte nas áreas císticas e da contínua deposição de matriz do esmalte pelos ameloblastos vizinhos, fato que pode ocorrer devido a uma alteração na secreção da matriz, após a degeneração dos processos de Tomes. 
Após a análise da função dos ameloblastos em ratos injetados com etidronato por meio de uma técnica de hidridização in situ utilizando a expressão do gene do RNAm da amelogenina e através da localização desta proteína por imunoistoquímica, foi demonstrado que o gene da amelogenina foi consistentemente expresso em ameloblastos tanto nas ilhas de esmalte formado, quanto nas zonas onde este tecido não foi depositado normalmente (Yamada et al., 2000). Resultado similar foi encontrado por Fuangtharnthip et al. (2000), após observarem que o etidronato não afeta a atividade ameloblástica na síntese de proteína, comprovando que a hipoplasia de esmalte em ratos tratados com etidronato pode não estar relacionada a um distúrbio na síntese protéica.

No estudo de Yamada et al. (2000), foi observado ainda que nos ameloblastos dos animais do grupo experimental havia pequenos grânulos imunorreativos para amelogenina, os quais não estavam presentes sobre os ameloblastos do grupo controle, indicando que a amelogenina foi secretada dessas células após sua síntese. Essas observações refletem a inibição do processo de secreção protéica, causado de alguma forma, por sucessivas injeções de etidronato (Fuangtharnthip et al., 2000; Yamada et al., 2000).

Este distúrbio é provavelmente causado pela degeneração dos processos de Tomes, após a administração do etidronato, como já citado anteriormente (Fouda et al., 1989). Os processos de Tomes estão presentes nos ameloblastos secretórios e desempenham um importante papel na secreção de proteínas do esmalte. Entretanto, é possível que o bisfosfonato possa afetar as proteínas em suas propriedades químicas, resultando em dificuldades de secreção e no acúmulo de amelogenina no citoplasma dos ameloblastos (Yamada et al., 2000).

Entretanto, nenhum desses defeitos no desenvolvimento do esmalte foi encontrado no presente estudo. Esta divergência possivelmente se deve a 2 fatos: 1) ao uso do alendronato sódico, e não do etidronato, como já salientado anteriormente; e 2) às doses extremamente elevadas empregadas nos estudos prévios com etidronato. Houve alguma variação entre as doses utilizadas nesses estudos $(5,8$ e $10 \mathrm{mgP} / \mathrm{Kg})$, porém todas podem ser consideradas elevadas com relação à dose administrada aos animais do grupo experimental do presente estudo.

A nosso ver, para uma possível extrapolação de resultados obtidos em modelos animais deve se utilizar uma dosagem comparável à humana, considerando também o índice metabólico do animal experimental. Este índice metabólico determina a velocidade e tempo em que a droga permanecerá em níveis terapeuticamente ativos na circulação sanguínea e nos tecidos. Para a determinação deste índice metabólico deve-se levar em conta o peso e a superfície corporal. O índice metabólico de cada animal é muito variável de espécie para espécie, sendo que os ratos têm um índice metabólico próximo a 2 vezes mais rápido que o do homem (Keidel, 1971). 
Com base nestes aspectos e na dose de alendronato recomendada para humanos, 0 protocolo de utilização da droga empregado neste estudo foi a adminstração de $1 \mathrm{mg} / \mathrm{Kg}$ de peso de alendronato sódico, duas vezes por semana, durante um período de 60 dias.

Além disso, nos estudos que verificaram alterações nas estruturas dentárias, após uso do etidronato, (Ogawa et al., 1989; Josephsen et al., 1990; Fejerskov et al., 1990; Weile et al., 1990; 1993; Fuangtharnthip et al., 2000; Yamada et al., 2000), o regime utilizado foi a injeção de uma dose única ou a administração diária da droga durante um curto intervalo de tempo.

Conforme esperado, a meia vida dos bisfosfonatos em humanos é muito maior do que nos ratos. Considerando a farmacocinética e o mecanismo de ação desses medicamentos, não se deve projetar trabalhos em ratos administrando os bisfosfonatos por períodos curtos, inferiores a um mês (Martins-Ortiz, 2004).

Para confirmar se a posologia utilizada para a administração do alendronato, no presente estudo, incluindo dose, via de administração, frequência e duração do tratamento, foi adequada em nível de efeitos sistêmicos esperados, a análise da densidade mineral óssea (BMD) foi conduzida empregando dois métodos diferentes: Densitometria Óptica Radiográfica e Absortometria Radiológica de Dupla Energia (DXA). Ambos demonstraram um aumento na densidade mineral da metáfise proximal da tíbia, após a exposição ao alendronato. Este resultado serviu como um controle para esta pesquisa, como efetuado em outros estudos sobre biologia óssea (Freundlich e Alon, 2008; Inoue et al., 2008; Kawate et al., 2010; Xu et al., 2010; Silva, 2010), comprovando que a administração sistêmica da droga foi realizada de maneira correta.

Valores de densidade mineral de ossos longos são amplamente utilizados para avaliar alterações no equilíbrio formação/reabsorção óssea, como indicativos de enfermidades ósseas. A absortometria radiológica de dupla energia (DXA), utilizada na prática clínica desde a década de 80 , é a técnica não invasiva mais empregada para avaliar a densidade mineral óssea (BMD) e o conteúdo mineral ósseo (BMC) em humanos e experimentalmente em animais (Lochmüller et al., 2001).

A DXA foi recentemente adaptada para a análise da composição mineral corporal de animais como ratos e camundongos, por meio da utilização de um software especializado acoplado ao equipamento (Nagy e Clair, 2000). Dentre estes equipamentos destaca-se o Lunar PIXImus, que se apresenta como método eficaz de determinação da densidade mineral óssea de animais de pequeno porte (Bartell et al., 2008; Earp et al., 2008; Katikaneni et al., 2009; Xu et al., 2010; Silva, 2010). No presente estudo, esse equipamento foi utilizado a fim de determinar a densidade mineral óssea nos animais dos diferentes grupos experimentais. 
Em geral, os defeitos observados na amelogênese e na formação do esmalte por bisfosfonatos podem ser um indicador de severas alterações celulares tóxicas, geradas pelas altas doses de etidronato empregadas. Em outras palavras, esses efeitos como a formação de cistos subameloblásticos são similares àqueles provocados por outros agentes, como flúor, tetraciclina e estrôncio, que sabidamente provocam toxicidade às células (Simmelink, 1987).

O comportamento dos bisfosfonatos é dose e tempo dependente e, segundo Yamada et al. (2000), os distúrbios na amelogênese ocorreram apenas quando a concentração sanguínea deste composto foi alta. Da mesma forma, Simmelink (1987) relatou que quando os BFs (HEBP e $\mathrm{Cl}_{2} \mathrm{MDP}$ ) foram injetados subcutaneamente em concentrações menores $(2,5 \mathrm{mg} / \mathrm{Kg})$, o efeito na amelogênese foi menor, uma vez que esta dose não causou a formação de cistos subameloblásticos, ao contrário de quando foram administradas doses maiores.

Essas informações fundamentam os achados do presente estudo, que não revelaram qualquer distúrbio no esmalte e na dentina de incisivos murinos, após a exposição ao alendronato administrado na dose de $1 \mathrm{mg} / \mathrm{Kg}$.

O etidronato (HEBP) é um dos bisfosfonatos básicos e apresenta um efeito inibitório relativamente maior na mineralização que na reabsorção óssea (Schenk et al., 1973). O etidronato é um bisfosfonato não aminado, diferente do alendronato, um aminobisfosfonato, que possui elevada afinidade mineral e potente atividade antirreabsortiva, dada a sua capacidade de afetar processos celulares bioquímicos, como a inibição da enzima farnesil pirofosfato sintase (FPPS) (Russell et al., 2008). Tais características podem ser utilizadas também para justificar os resultados do presente estudo, que divergem da maioria dos achados de outros pesquisadores, que demonstraram diversos distúrbios nos tecidos dentários mineralizados, incluindo hipomineralização, hipoplasias e cistos, quando utilizaram o etidronato (Beertsen et al., 1985; Simmelink, 1987; Ogawa et al., 1989; Fejerskov et al., 1990; Josephsen et al., 1990; Weile et al., 1990; Fouda et al., 1991; Weile et al., 1993; Takano et al., 1998; Sakai et al., 1999; Fuangtharnthip et al., 2000; Yamada et al., 2000; Ohma et al., 2000). No presente estudo, não foi possível observar qualquer efeito significativo do alendronato sódico na formação do esmalte e da dentina de incisivos de ratos, por meio das metodologias empregadas.

Segundo Sakai et al. (1999), quando os animais receberam uma dose maior, 20mgP/Kg/dia de HEBP, a inibição da mineralização da dentina foi drasticamente maior, indicando que a dose utilizada influencia significativamente nos efeitos gerados, ou seja, que os efeitos são dose-dependentes. 
Por outro lado, segundo Ogawa et al. (1989), o esmalte é mais susceptível à hipomineralização induzida pelo etidronato do que a dentina, uma vez que com $1 \mathrm{mgP} / \mathrm{Kg}$ da droga (injeção única), a faixa hipomineralizada foi claramente visível no esmalte, enquanto que a lesão hipomineralizada foi parcialmente desenvolvida na dentina.

Foi visto que o etidronato afeta a síntese e as propriedades biológicas de glicosaminoglicanas, proteoglicanas, colágeno e fosfolipídeos (Larsson, 1974). Isto indica que este composto pode ter efeitos muito mais complexos nos tecidos mineralizados (Ogawa et al., 1989).

Larsson e Larsson (1973) relataram que mesmo com doses relativamente baixas de etidronato $(0,5$ e 2,5mg/Kg), o BF provocou inibição da formação dos cristais e um aumento na largura da pré-dentina, além de distúrbios na formação de fibras colágenas nas áreas de pré-dentina recentemente depositadas. Os ratos que receberam a solução contendo etidronato exibiram cristalitos de tamanho menor que aqueles observados em dentina normal. Entretanto, estas mudanças foram mais pronunciadas nos animais que receberam a dose maior do BF.

Os resultados do presente estudo são discordantes desses achados prévios, já que não foi possível detectar distúrbios no tecido dentinário mineralizado, indicando que muito provavelmente também não houve qualquer alteração na pré-dentina e na taxa de aposição da dentina.

No estudo realizado por Massa et al., em 2006, também foi empregado o alendronato. O objetivo foi avaliar o efeito desta droga (2,5mg/Kg/dia por 3 dias), por meio de imunoistoquímica, na deposição de amelogenina durante os estágios iniciais da odontogênese de molares de ratos recém-nascidos. A análise dos cortes dos espécimes tratados com alendronato revelou alterações evidentes na matriz extracelular em todos os estágios da odontogênese, quando comparados ao grupo controle. Com base nos resultados obtidos, os autores afirmaram que o principal efeito do alendronato foi romper o equilíbrio de secreção/degradação de amelogenina na matriz de esmalte, que é controlado pelos ameloblastos durante o estágio secretório da amelogênese. Embora os achados sugiram que as moléculas desta proteína tenham sido secretadas em excesso pelos ameloblastos, é possível que elas possam ter sido insuficientemente degradadas durante o período secretório da amelogênese. Como os BFs demonstraram inibir MMPs, estas drogas podem atuar durante a odontogênese afetando a função da MMP-20 (enamelisina) e de outras enzimas que agem na fase secretória da amelogênese (Massa et al., 2006). Apesar de terem utilizado o alendronato, assim como no presente estudo, não podemos afirmar que os resultados por nós obtidos foram discordantes dos descritos por Massa et al. (2006), uma vez que a dose 
empregada, a freqüência e a duração do tratamento foram diferentes em ambos os estudos. Além disso, as análises nos dois estudos foram diferentes, o que impossibilita a comparação direta dos resultados.

Por outro lado, este foi o primeiro estudo que analisou, por meio de métodos químicos, se o alendronato se incorpora à estrutura dentária durante a mineralização. Segundo a análise por espectrometria na região do infravermelho, foi possível inferir a presença de alendronato sódico na amostra do grupo experimental. De acordo com o teste de espectroscopia de fluorescência também empregado, foi possível determinar a quantidade de droga encontrada, em média, em cada elemento dental, que foi de aproximadamente 0,0018\%, um valor relativamente baixo. Entretanto, este é um resultado muito valioso que comprova a elevada afinidade deste composto pela hidroxiapatita, fazendo com que seja rapidamente incorporado à matriz em mineralização, seja de tecido ósseo ou de outros tecidos mineralizados, inclusive o dente.

Os BFs são caracterizados por uma ligação P-C-P central em sua estrutura química, o que os torna semelhantes estruturalmente ao pirofosfofato inorgânico, que contêm um átomo de oxigênio ao invés de um átomo de carbono (Russell e Smith, 1973). Ao contrário do pirofosfato, os BFs são resistentes à hidrólise química e enzimática (Russell et al., 2008). Entretanto, apresentam propriedades similares, como inibir a precipitação de fosfato de cálcio, bloquear a transformação de fosfato de cálcio amorfo em hidroxiapatita e retardar o crescimento e a dissolução de cristais existentes (Fleisch et al., 1969).

De fato, os achados atuais corroboram com as propriedades físico-químicas já conhecidas dos BFs e com a sua capacidade de ligação a íons divalentes, como o cálcio, conferida pela estrutura P-C-P.

Diferente de outros tecidos mineralizados, nos quais o mineral é depositado em direção a uma matriz orgânica, o esmalte perde a grande maioria das proteínas e da água presente em sua matriz orgânica durante o progresso de sua formação, também conhecido como amelogênese, resultando no tecido mais mineralizado em mamíferos. Por esta razão, o esmalte não pode sofrer remodelação uma vez concluída sua formação e, consequentemente, substâncias incorporadas ou alterações em sua estrutura são marcas (características) permanentes (Gerlach et al., 2002).

No presente estudo, quando o elemento dental foi analisado quimicamente, foi possível detectar a presença do alendronato, o que indica que esta substância estava biodisponível no organismo no momento da formação do dente. A quantidade detectada de 0,0018\% possivelmente não foi suficiente para causar alterações significativas. 
No entanto, no presente estudo, as análises por espectrometria na região do infravermelho e por espectroscopia de fluorescência foram realizadas no elemento dental como um todo, tornando impossível distinguir se o alendronato estava presente no esmalte e/ou na dentina e se houve diferença no nível de incorporação entre estes dois substratos.

Martins-Ortiz (2004) observou, em estudo histopatológico, que a administração de alendronato desde o início da odontogênese, via gavagem, reduziu a incidência de reabsorções radiculares, após movimentação dentária induzida em dentes de ratos, sugerindo que o alendronato pode aumentar a resistência dos tecidos à reabsorção dentária. De acordo com os parâmetros avaliados neste estudo, incluindo microdureza transversal, microscopia eletrônica de varredura e microscopia de luz polarizada, a incorporação do alendronato à estrutura dentária não foi capaz de provocar nenhum efeito.

Fica claro, assim, a necessidade de estudos adicionais para avaliar se este composto, uma vez presente no dente, pode alterar suas propriedades físicas, químicas, biológicas ou mesmo estéticas, segundo outros parâmetros de avaliação, incluindo resistência à desmineralização ácida após desafios cariogênicos, o que poderia tornar o elemento dental mais ou menos susceptível à cárie ou mesmo a processos erosivos. 


\section{Conclusão}




\section{CONCLUSÃo}

Considerando as condições específicas deste trabalho e com base nos resultados obtidos nas diferentes metodologias empregadas, pôde-se concluir que:

- O tratamento com alendronato sódico provocou aumento na densidade mineral óssea da metáfise proximal da tíbia de ratos, evidenciado por meio das técnicas de densitometria óptica radiográfica e absortometria radiológica de dupla energia (DXA).

- O alendronato sódico sofreu incorporação nas estruturas dentárias mineralizadas, evidenciada por meio de espectrometria na região do infravermelho e espectroscopia de fluorescência. Entretando, os estudos de microdureza transversal, microscopia eletrônica de varredura e microscopia de luz polarizada não evidenciaram efeitos significativos dessa incorporação no esmalte e na dentina de incisivos de ratos. 
Referências 


\section{REFERÊNCIAS ${ }^{1}$}

Arana-Chaves VE, Massa LF. Odontoblasts: the cells forming and maintaining dentine. Int J Biochem Cell Biol 2004;36:1367-73.

Atas A, Cakmak A, Soran M, Soker M, Varma M. Severe osteoporosis and high level TSH in a child before the diagnosis of acute lymphoblastic leukemia. J Pediatr Hematol Oncol 2009;31:588-91.

Bachrach LK, Ward LM. Clinical Review: Bisphosphonate Use in Childhood Osteoporosis. J Clin Endocrinol Metab 2009;94:400-9.

Bartell SM, Isales CM, Baile CA, Kuhar MJ, Hamrick MW. CART deficiency increases body weight but does not alter bone strength. J Musculoskelet Neuronal Interact 2008;8:146-53.

Baumann JM, Bisaz S, Fleisch H, Wacker M. Biochemical and clinical effects of ethane-1-hydroxy-1,1diphosphonate in calcium nephrolithiasis. Clin Sci Mol Med 1978;554:509-16.

Beertsen W, Niehof A, Everts V. Effects of 1-hydroxyethylidene-1,1-bisphosphonate (HEBP) on the formation of dentin and the periodontal attachment apparatus in the mouse. Am J Anat 1985;174:83103.

Boivin G, Meunier P. Effects of bisphosphonates on matrix mineralization. J Musculoskel Neuron Interact 2002;2:538-43.

Bone HG, Downs RW, Tucci JR, Harris ST, Weinstein RS, Licata AA, McClung MR, Kimmel DB, Gertz $B J$, Hale $E$, Polvino WJ. Dose-response relationships for alendronate treatment in osteoporotic elderly women. Alendronate Elderly Osteoporosis Study Centers. J Clin Endocrinol Metab 1997;82:265-74.

Bradaschia-Correa V, Massa LF, Arana-Chavez VE. Effects of alendronate on tooth eruption and molar root formation in young growing rats. Cell Tissue Res 2007; 330:475-85.

Breen SA, Loveday BE, Millest AJ, Waterton JC. Stimulation and inhibition of bone formation: use of peripheral quantitative computed tomography in the mouse in vivo. Lab Anim 1998;32:467-76.

Consolaro A. Reabsorções dentárias nas especialidades clínicas. 2 ed. Maringá, PR: Dental Press, 2005.

\footnotetext{
${ }^{1}$ Normas internas do Programa de Pós-Graduação em Odontopediatria da FORP-USP (2009), de acordo com o International Comitte of Medicals Journals Editors. Uniform Requirements for manuscripts submitted to Medical Journal, 1997. Disponivel em: http://www.mja.com.au/public/information/uniform.html. Acesso em agosto de 2010.
} 
Cecim PES. Uso de alendronato de sódio em ratas submetidas à imobilização gessada. Análise de propriedades mecânicas do femur e da densidade óssea radiográfica do colo femoral. Dissertação (Mestrado) - Faculdade de Medicina de Ribeirão Preto, Universidade de São Paulo. Ribeirão Preto, $200788 p$.

De Marco J, Biffar S, Reed DG, Brooks MA. The determination of 4-amino-I-hydroxybutanel, Idiphosphonic acid monosodium salt trihydrate in pharmaceutical dosage forms by high-performance liquid chromatography. J Pharm Biomed Anal 1989;7:1719-27.

Drake MT, Cremers SC. Bisphosphonate therapeutics in bone disease: the hard and soft data on osteoclast inhibition. Mol Interv 2010;10:141-52.

Drake WM, Kendler DL, Brown JP. Consensus statement on the modern therapy of Paget's disease of bone from a Western Osteoporosis Alliance symposium. Biannual Foot-hills Meeting on Osteoporosis, Calgary, Alberta, Canada, September 9-10, 2000. Clin Ther 2001;23:620-6.

Earp JC, Dubois DC, Molano DS, Pyszczynski NA, Keller CE, Almon RR, Jusko WJ. Modeling corticosteroid effects in a rat model of rheumatoid arthritis I: mechanistic disease progression model for the time course of collagen-induced arthritis in Lewis rats. Pharmacol Exp Ther 2008;326:532-45.

Ebetino FH, Francis MD, Rogers MJ, Russell RGG. Mechanisms of action of etidronate and other bisphosphonates. Rev Contemp Pharmacother 1998;9:233-43.

Fejerskov O, Josephsen K, Weile V. The effect of a single dose of 1-hydroxyethylidene-1,1bisphosphonate (HEBP) on secretory ameloblasts and enamel formation in rat incisors. J Biol Buccale 1990;18:339-54.

Fleisch H. Bisphosphonates: mechanisms of action. Endocr Rev 1998;19:80-100.

Fleish H. Development of bisphosphonates. Breast Cancer Res 2002;4:30-4.

Fleisch H, Russell RGG, Francis MD. Diphosphonates inhibit hydroxyapatite dissolution in vitro and bone resorption in tissue culture and in vivo. Science 1969;165:1262-4.

Fouda N, Caracatsanis M, Hammarstrom L. Developmental Disturbances of the Rat Molar Induced By Two Diphosphonates. Adv Dent Res 1989;3:234-40.

Fouda N, Caracatsanis M, Kut IA, Hammarstrom L. Mineralization disturbances of the developing rat molar induced by mono- and bisphosphonates. J Biol Buccale 1991;19:106-15.

Fouda N, Kut IA, Hammarstrom L. Effects of phosphonoformic acid and 1-hydroxyethylidene-1,1bisphosphonate (HEBP) on distribution of tetracycline in the developing rat molar. Scand J Dent Res 1992;100:257-65. 
Freundlich M, Alon US. Bisphosphonates in children with hypercalciuria and reduced bone mineral density. Pediatr Nephrol 2008;23:2215-20.

Fuangtharnthip P, Yamada Y, Takagi Y, Ohya K. Autoradiographic investigation of the effect of 1hydroxyethylidene-1, 1-bisphosphonate on matrix protein synthesis and secretion by secretoryameloblasts in rat incisors. Arch Oral Biol 2000;45:495-506.

Gerlach RF, Cury JA, Krug FJ, Line RP. Effect of lead on dental enamel formation. Toxicol 2002;175:27-34.

Ghoneima AA, Allam ES, Zunt SL, Windsor $\mathrm{L}$. Bisphosphonates treatment and orthodontic considerations. Orthod Craniofac Res 2010;13:1-10.

Inoue $\mathrm{Y}$, Shimojo N, Suzuki S, Arima T, Tomiita M, Minagawa M, Kohno Y. Efficacy of intravenous alendronate for the treatment of glucocorticoid-induced osteoporosis in children with autoimmune diseases. Clin Rheumatol 2008;27:909-12.

Josephsen K, Fejerskov O, Baelum V, Weile V. The effect of a single dose of 1-hydroxyethylidene-1,1bisphosphonate (HEBP) on presecretory ameloblast differentiation in rat incisors. J Biol Buccale 1990;18:321-37.

Kanzaki S, Takada Y, Ogawa K, Matsuo K. Bisphosphonate Therapy Ameliorates Hearing Loss in Mice Lacking Osteoprotegerin. J Bone Miner Res 2009;24:43-9.

Katikaneni R, Ponnapakkam A, Miller E, Ponnapakkam T, Gensure RC. A new technique for precisely and accurately measuring lumbar spine bone mineral density in mice using clinical dual energy $X$-ray absorptiometry (DXA). Toxicol Mech Methods 2009;19:225-31.

Kawate H, Ohnaka K, Adachi M, Kono S, Ikematsu H, Matsuo H, Higuchi K, Takayama T, Takayanagi R. Alendronate improves $\mathrm{QOL}$ of postmenopausal women with osteoporosis. Clin Interv Aging 2010;5:123-31.

Keidel WD. Fisiologia. 2.ed., Barcelona, Salvat, 1971.

Larsson A e Larsson SE. Studies on Dentinogenesis in the Rat. Ethane-1-Hydroxyl-1,1-Diphosphonate (EHDP) Inhibits Crystal Growth in Predentin Calcification. Virchows Arch Abt A Path Anat 1973;360:315-25.

Larsson A. The short-term effects of high doses of ethylene-1-hydroxy-1,1-diphosphonates upon early dentin formation. Calcif Tissue Res 1974;16:109-27. 
Leanne W, Andrea T, Phuc-Nhi P, Ann C, Nick B, Isabelle G, Frank R, Peter T, David M. Bisphosphonate therapy for children and adolescents with secondary osteoporosis. Cochrane Database of Systematic Reviews, Issue 3, 2009.

Lewiecki EM. Intravenous zoledronic acid for the treatment of osteoporosis: The evidence of its therapeutic effect. Core Evid 2010;4:13-23.

Lochmüller EM, Jung V, Weusten A, Wehr U, Wolf E, Eckstein F. Precision of high-resolution dual energy $\mathrm{X}$-ray absorptiometry of bone mineral status and body composition in small animal models. Eur Cell Mater 2001;1:43-51.

Maranho DS, Lima RG, Primo FL, Silva RS, Tedesco AC. Photoinduced Nitric Oxide and Singlet Oxygen Release from ZnPC Liposome Vehicle Associated with the Nitrosyl Ruthenium Complex: Synergistic Effects in Photodynamic Therapy Application. Photochem Photobiol 2009;85:705-13.

Martins-Ortiz MF. Influência dos bisfosfonatos na movimentação dentária induzida, nas freqüência e nas dimensões das reabsorções radiculares associadas. Tese (Doutorado) - Faculdade de Odontologia de Bauru, Universidade de São Paulo. Bauru, 2004 187p.

Massa LF, Bradaschia-Correa V, Arana-Chavez VE. Immunocytochemical Study of Amelogenin Deposition during the Early Odontogenesis of Molars in Alendronate-treated Newborn Rats. J Histochem Cytochem 2006;54:713-25.

Møinichen CB, Lyngstadaas SP, Risnes S. Morphological characteristics of mouse incisor enamel. J Anat 1996;189:325-33.

Nagy TR, Clair AL. Precision and accuracy of dual-energy X-ray absorptiometry for determining in vivo body composition of mice. Obes Res 2000;8:392-8.

Nanci A, Zalzal S, Lavoie P, Kunikata M, Chen WY, Krebsbach PH, Yamada Y, Hammarström L, Simmer JP, Fincham AG, Snead ML, Smith CE. Comparative immunochemical analyses of developmental expression and distribution of ameloblastin and amelogenin in rat incisors. J Histochem Cytochem 1998;46:911-34.

Ogawa Y, Adachi Y, Hong S, Yagi T. 1-hydroxyethylidene-1,1-bisphosphonate (HEBP) simultaneously induces two distinct types of hypomineralization in the rat incisor dentine. Calcif Tissue Int 1989;44:46-60.

Ohma N, Takagi Y, Takano Y. Distribution of non-collagenous dentin matrix proteins and proteoglycans, and their relation to calcium accumulation in bisphosphonate-affected rat incisors. Eur J Oral Sci 2000;108:222-32. 
Ohya K, Mataki S, Wakamatsu H, Ogura H. Effects of successive injections of 1-hydroxyethylidene-1, 1-bisphosphonate (HEBP) on the rat incisors enamel. In Fearnhead RW, ed. Tooth Enamel V, Yokohama, Florence Publishers 1989;227-34.

Okada Y, Nawata M, Nakayamada S, Saito K, Tanaka Y. Alendronate Protects Premenopausal Women form Bone Loss and Fracture Associated with High-dose Glucocorticoid Therapy. J Rheumatol 2008;35:2249-54.

Oliveira MTM, Macedo LD, Bel EAD, Watanabe P, Albuquerque Jr RF. Avaliação da densitometria óssea de tecido ósseo neoformado após distração osteogênica mandibular. Rev Dent Press Ortodon Ortop Facial 2006;11:37-43.

Orbak Z, Doneray H, Keskin F, Turgut A, Alp H, Karakelleoglu C. Vitamin D intoxication and therapy with alendronate (case report and review of literature). Eur J Pediatr 2006;165:583-4.

Ozbek M, Dural S, Kankli A, Tuncel M, Orhan K. Morphological Evaluation of Rat Incisor Enamel and Dentin Induced by Pregnancy and Lactation using A Scanning Electron Microscope. J Vet Med Sci 2009;71:1273-7.

Pazianas M, Cooper C, Ebetino FH, Russell RGG. Long-term treatment with bisphosphonates and their safety in postmenopausal osteoporosis. Clin Interv Aging 2010;6:325-43.

Porto IM, Merzel J, Sousa FB, Bachmann L, Cury JA, Line SR, Gerlach RF. Enamel mineralization in the absence of maturation stage ameloblasts. Arch Oral Biol 2009;54:313-21.

Rehder Neto FC. Estudo da progressão e inibição de lesões artificiais de cárie através de alterações da microdureza superficial. Dissertação (Mestrado) - Faculdade de Odontologia de Ribeirão Preto, Universidade de São Paulo. Ribeirão Preto, 2008 77p.

Reid DM. Update on the use of zoledronic acid in the management of osteoporosis. Curr Osteoporos Rep 2010;8:145-50.

Reid IR. Bisphosphonates: new indications and methods of administration. Curr Opin Rheumatol 2003;15:458-63.

Ribeiro AF, Volpato NM. Alendronato de sódio: Metodologias para análise quantitativa. Quim Nova $2005 ; 28: 852-8$.

Robinson C, Briggs HD, Atkinson PJ, Weatherell JA. Matrix and mineral changes in developing enamel. J Dent Res 1979;58:871-82.

Roelofs A, Thompson K, Gordon S, Rogers M. Molecular mechanisms of action of bisphosphonates: current status. Clin Cancer Res 2006;20(Suppl):6222-30. 
Rogers M, Gordon S, Benford H, Coxon F, Luckman S, Monkkonen J, Frith JC. Cellular and molecular mechanisms of action of bisphosphonates. Cancer 2000;88:2961-78.

Rosen CJ, Hochberg MC, Bonnick SL, McClung M, Miller P, Broy S, Kagan R, Chen E, Petruschke RA, Thompson DE, Papp AE. Treatment with once-weekly alendronate $70 \mathrm{mg}$ compared with once-weekly risedronate $35 \mathrm{mg}$ in women with postmenopausal osteoporosis: a randomized double-blind study. J Bone Miner Res 2005;20:141-51.

Russell RGG. Bisphosphonates: Mode of Action and Pharmacology. Pediatrics 2007;119:S159-62.

Russel RGG, Rogers MJ. Bisphosphonates: from the laboratory to the clinic and back again. Bone $1999 ; 25: 97-106$.

Russell RGG, Smith R. Diphosphonates. Experimental and clinical aspects. J Bone Joint Surg $1973 ; 55: 66-86$.

Russell RGG, Xia Z, Dunford JE, Oppermann U, Kwaasi A, Hulley PA, Kavanagh KL, Triffitt JT, Lundy MW, Phipps RJ, Barnett BL, Coxon FP, Rogers MJ, Watts NB, Ebetino FH. An update on Mechanisms of Action and How These Relate to Clinical Efficacy. Acad Sci 2007;1117:209-57.

Russell RGG, Watts NB, Ebetino FH, Rogers MJ. Mechanisms of action of bisphosphonates: similarities and differences and their potential influence on clinical efficacy. Osteoporos Int 2008;19:733-59.

Sahni M, Guenther HL, Fleisch H, Collin P, Martin TJ. Bisphosphonates act on rat bone resorption through the mediation of osteoblasts. J Clin Invest 1993;91:2004-11.

Saiani RA, Porto IM, Marcantonio Junior E, Cury JA, Sousa FB, Gerlach RF. Morphological characterization of rat incisor fluorotic lesions. Arch Oral Biol 2009;54:1008-15.

Sakai H, Takano Y, Ohya K, Kurosaki N. Intermittent inhibition of dentin mineralization of rat incisors under continual infusion of 1-hydroxyethylidene-1,1-bisphosphonate (HEBP) using subcutaneous mini osmotic pump. Arch Histol Cytol 1999;62:171-9.

Salo J, Lenenkari P, Mulari M, Metsikko K, Vaananen HK. Removal of osteoclast bone resorption products by transcytosis. Science 1997;276:270-3.

Sansoni P, Passeri G, Fagnoni F, Mohagheghpour N, Snelli G, Brianti V, Engleman EG. Inhibition of antigen-presenting cell function by alendronate in vitro. J Bone Miner Res 1995;10:1719-25.

Sato M, Grasser W, Endo N, Akins R, Simmons H, Thompson DD, Golub E, Rodan GA. Bisphosphonates action. Alendronate localization in rat bone and effects on osteoclast ultrastructure. J Clin Invest 1991; 88:2095-2105. 
Sato K, Hattori M, Aoba T. Disturbed Enamel Mineralization in a Rat Incisor Model. Adv Dent Res 1996;10:216-24.

Schenk R, Merz WA, Mühlbauer R, Russell RGG, Fleisch H. Effect of ethane-1-hydroxy-1,1diphosphonate (EHDP) and dichloromethylene diphosphonate $\left(\mathrm{Cl}_{2} \mathrm{MDP}\right)$ on the calcification and resorption of cartilage and bone in the tibial epiphysis and metaphysic of rats. Calcif Tissue Res 1973;11:196-214.

Schmidt C, Priemel M, Kohler T, Weusten A, Müller R, Amling M, Eckstein F. Precision and Accuracy of Peripheral Quantitative Computed Tomography (pQCT) in the Mouse Skeleton Compared With Histology and Microcomputed Tomography $(\mu C T)$. J Bone Miner Res 2003;18:1486-96.

Silva RAB. Expressão in vitro e in vivo da Proteína PAMM, após indução de stress oxidativo. Tese (Livre-Docência) - Faculdade de Odontologia de Ribeirão Preto/USP. Ribeirão Preto, 2010 62p.

Silverman SL, Watts NB, Delmas PD, Lange JL, Lindsay R. Effectiveness of bisphosphonates on nonvertebral and hip fractures in the first year of therapy: the risedronate and alendronate (REAL) cohort study. Osteoporos Int 2007;18:25-34.

Simmelink JW. Ultrastructural effects of diphosphonates on dental enamel. Adv Dent Res 1987;1:35665.

Small BW, Murray JJ. Enamel opacities: prevalence, classifications and aetiological considerations. J Dent 1978;6:33-42.

Srivastava T, Alon US. The role of bisphosphonates in diseases of childhood. Eur J Pediatr 2003; 162:735-51.

Suckling GW. Developmental defects of enamel- Historical and present-day perspectives on their pathogenesis. Adv Dent Res 1989;3:87-94.

Takano Y, Sakai H, Baba O, Sakamoto Y, Terashima T, Ohya K, Kurosaki N. Demonstration of putative Ca-binding domains in dentin matrix of rat incisors after daily injections of 1-hydroxyethylidene-1,1bisphosphonate (HEBP). Eur J Oral Sci 1998;106 Suppl 1:274-81.

Thesleff I, Vaahtokari A, Kettunen P, Aberg T. Epithelialmesenchymal signaling during tooth development. Connect Tissue Res 1995;32:9-15.

Thompson K, Rogers MJ, Coxon FP, Crockett JA. Cytosolic entry of bisphosphonate drugs requires acidification of vesicles after fluid-phase endocytosis. Mol Pharmacol 2006;69:1624-32. 
Van Beek E, Löwik C, Que I, Papapoulos S. Dissociation of binding and antiresorptive properties of hydroxybisphosphonates by substitution of the hydroxyl with an amino group. J Bone Miner Res 1996;11:1492-7.

van den Bos T, Beertsen W. Effects of 1-hydroxyethylidene-1, 1-bisphosphonate (HEBP) on the synthesis of dentin matrix proteins in the mouse. Coll Relat Res 1987;7:135-47.

Vasikaran SD. Bisphosphonates: an overview with special reference to alendronate. Ann Clin Biochem 2001;38:608-23.

Vieira APGF, Hanocock R, Eggertsson H, Everett ET, Grynpas MD. Tooth Quality in Dental Fluorosis: Genetic and Environmental Factors. Calcif Tissue Int 2005;76:17-25.

Watts NB, Diab DL. Long-term use of bisphosphonates in osteoporosis. J Clin Endocrinol Metab 2010;95:1555-65.

Weile V, Josephsen K, Fejerskov O. Effects of single doses of 1-hydroxyethylidene-1,1-bisphosphonate on the mineralizing front of rat incisor enamel: a microradiographic and scanning electron microscopic study. Archs oral Biol 1990;35:857-67.

Weile V, Josephsen K, Fejerskov O. Scanning electron microscopy of final enamel formation in rat mandibular incisors following single injections of 1-hydroxyethylidene-1,1-bisphosphonate. Calcif Tissue Int 1993;52:318-24.

Yamada Y, Fuangtharnthip P, Tamura Y, Takagi Y, Ohya K. Gene expression and immunolocalization of amelogenin in enamel hypoplasia induced by successive injections of bisphosphonate in rat incisors. Arch Oral Biol 2000;45:207-15.

Xu Y, Morse LR, Silva RAB, Odgren PR, Sasaki H, Stashenko P, Battaglino RA. PAMM: a redox regulatory protein that modulates osteoclast differentiation. Antioxid Redox Signal 2010;13:27-37. 
Anexo 


\title{
Anexo A - Aprovação do Comitê de ÉticA
}

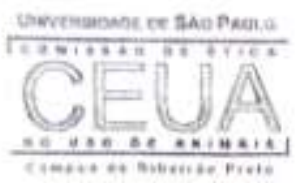

\author{
UNIVERSIDADE DE SĀO PAULO \\ Campus de Ribeirāo Preto \\ Comissão de Éticu no Ulso de Animais
}

\section{E R T I F I C A D O}

Certificamos que o trabalho (Protocolo $n^{\circ}$ 10.1.468.53.5), intitulado "Avaliaçāo do Éfeito do Alendronato no Esmalte e na Dentina de Incisivos Murinos", de autoria de Marilia Pacifico Lucisano e de Paulo Nelson Filho por estar de acordo com os Princípios Éticos na Experimentação Animal adotado pela Comissão de Ética no Uso de Animais (CEUA) do Campus de Ribeirão Preto - USP foi aprovado em reunião da CEUA

This is to certify that the work (Protocol number 10.1.468.53.5), entitled: "Avaliaçăo do Efeito do Alendronato no Esmalte e na Dentina de Incisivos Murinos", by Marilia Pacifico Lucisano and Paulo Nelson Filho, is in accordance with the Ethic Principles in Animal Experimentation adopted by Ethic Commission for the Use of Animals (CEUA) of the Campus of Ribeirão Preto - USP, and was approved in the meeting

Presidente da CEUA

Profa.Dra. Christie Ramos Andrade Leite Panissi

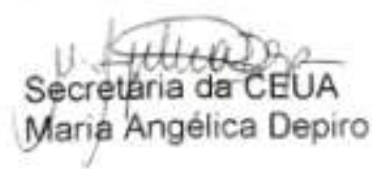

Av. Bandeirantes, 3900 - CEP $14040-900$ - Ribeirăo Prato - Sajo Paulo Fone (16) 36024469 - Fax (16) 36023534 